Florida State University College of Law

Scholarship Repository

Scholarly Publications

Summer 1999

\title{
Liberty Interests in the Preventive State: Procedural Due Process and Sex Offender Community Notification Laws
}

Wayne A. Logan

Florida State University College of Law

Follow this and additional works at: https://ir.law.fsu.edu/articles

Part of the Constitutional Law Commons, and the Criminal Law Commons

\section{Recommended Citation}

Wayne A. Logan, Liberty Interests in the Preventive State: Procedural Due Process and Sex Offender Community Notification Laws, 89 J. CRIM. L. \& CRIMINOLOGY 1167 (1999),

Available at: https://ir.law.fsu.edu/articles/201

This Article is brought to you for free and open access by Scholarship Repository. It has been accepted for inclusion in Scholarly Publications by an authorized administrator of Scholarship Repository. For more information, please contact efarrell@law.fsu.edu. 


\section{Journal of Criminal Law and Criminology}

Volume 89

Issue 4 Summer

Article 1

Summer 1999

Liberty Interested in the Preventive State:

Procedural Due Process and Sex Offender Community Notification Laws

Wayne A. Logan

Follow this and additional works at: http://scholarlycommons.law.northwestern.edu/jclc

Part of the Criminal Law Commons, $\underline{\text { Criminology Commons, and the Criminology and Criminal }}$ Justice Commons

\section{Recommended Citation}

Wayne A. Logan, Liberty Interested in the Preventive State: Procedural Due Process and Sex Offender Community Notification Laws, 89 J. Crim. L. \& Criminology 1167 (1998-1999)

This Criminal Law is brought to you for free and open access by Northwestern University School of Law Scholarly Commons. It has been accepted for inclusion in Journal of Criminal Law and Criminology by an authorized administrator of Northwestern University School of Law Scholarly Commons. 


\title{
CRIMINAL LAW
}

\section{LIBERTY INTERESTS IN THE PREVENTIVE STATE: PROGEDURAL DUE PROGESS AND SEX OFFENDER COMMUNITY NOTIFICATION LAWS}

\author{
WAYNE A. LOGAN*
}

"Am I not what I am, to some degree, in virtue of what others think and feel me to be?"1

\section{INTRODUCTION}

Sex offenders are the scourge of modern America, ${ }^{2}$ the "irredeemable monsters" who prey on the innocent. ${ }^{3}$ Although this revulsion is perhaps now more widespread and more acute, it is not unprecedented in the annals of American justice. During the twentieth century alone, those accused or convicted of sex offenses have been the subject of repeated social control strategies, including the "sexual psychopath" laws in effect nationwide since the 1930s, which segregate offenders in mental institutions. ${ }^{4}$ For its part, the U.S. Supreme Court has been no-

- Assistant Professor, State University of New York at Albany, School of Criminal Justice. B.A., Wesleyan University; M.A., State University of New York at Albany; J.D., University of Wisconsin. I thank Professors James Acker, David Logan, and Ron Wright for their thoughtful comments and suggestions in the preparation of this Article.

'SIR ISAIAH BERLIN, FOUR ESSAYS ON LIBERTY 155 (1969).

2 See, e.g., ADAM SAMPSON, ACts OF ABUSE: SEX OfFenders AND tHE CRIMINAL Justice System 124 (1994) ("The vehemence of the hatred for sex offenders is unmatched by attitudes to any other offenders."); Peter Davis, The Sex Offender Next Door, N.Y. Times MAGazine, July 28, 1996, at 20 (analogizing released sex offenders to lepers).

${ }^{3}$ David van Biema, Burn Thy Neighbor, TiME, July 26, 1993, at 58.

'See Marna J. Johnson, Comment, Minnesota's Sexual Psychopathic Personality and Sexually Dangerous Person Statute: Throwing Away the Key, 21 WM. MrTCHELL L. REv. 1139, 1141-47 (1996) (describing origins of sexual psychopath statutes and Supreme Court's case law relating thereto). 
tably unreceptive to constitutional challenges brought against such strategies, ${ }^{5}$ signaling its plain deference to the police power of states to target sex offenders with invasive and often quite novel interventions. ${ }^{6}$

In 1997, for instance, in Kansas v. Hendricks, the Court upheld the nominally "civil" scheme used by Kansas to involuntarily commit "sexually violent predators" after their release from prison. While observing that "freedom from physical restraint 'has always been at the core of the liberty protected by the Due Process Clause,", eight justices reaffirmed that this "liberty interest is not absolute." The states, the Hendricks Court emphasized, should be afforded latitude to formulate their own methods of controlling sex offenders. ${ }^{10}$

This article addresses yet another police power strategy used by governments seeking to control sex offenders, a strategy that

s See, e.g., Allen v. Illinois, 478 U.S. 364, 375 (1986) (denying claims based on due process and the violation of the privilege against self-incrimination against an Illinois law that permitted indefinite "civil confinement" of sex offenders in state maximum security prisons); Minnesota ex rel. Pearson v. Probate Court, 309 U.S. 270, 276 (1940) (denying due process and equal protection challenges to Minnesota's "sexual psychopath" law, which diverted suspects to treatment facilities in lieu of prison). But see Specht v. Patterson, 386 U.S. 605, 610 (1967) (striking down on procedural due process grounds a sex offender sentence enhancement on reasoning that "the invocation of the [Colorado] Sex Offenders Act means the making of a new charge leading to criminal punishment").

Although significant for its deviation from the Court's otherwise uniform approval of sex offender laws, Specht is also distinctive for its express emphasis on the criminal (not civil) nature of the proceeding at issue, and the undisputed greater concern for due process protections in criminal proceedings. As the courts have overwhelmingly found, registration and notification provisions are "civil" regulations, thus not triggering the full panoply of constitutional protections available to those in the criminal cross-hairs of the State. See infra note 17 and accompanying text.

-Police power" involves the State's capacity to enact laws "promot[ing] the health, peace, morals, education, and good order of the people." Barbier v. Connolly, 113 U.S. 27,31 (1885). See also United States v. Salerno, 481 U.S. 739, 747 (1987) ("There is no doubt that preventing danger to the community is a legitimate regulatory goal.").

${ }^{2} 521$ U.S. 346 (1997).

${ }^{8}$ Id. at 356 (quoting Foucha v. Louisiana, 504 U.S. 71, 80 (1992)).

${ }^{9}$ See id. at 360.

Justice Ginsburg was the sole dissenter on the question of whether the Kansas Act violated substantive due process. Id. at 373 (Ginsburg, J., dissenting). Justice Ginsburg did, however, join three of her colleagues-Justices Breyer, Stevens, and Souter-in dissenting on the ground that the Act amounted to "punishment, "imposed retroactively, in violation of the Ex Post Facto Clause. Id. See generally Wayne A. Logan, The Ex Post Facto Clause and the Jurisprudence of Punishment, 35 AM. CRIM. L. REV. 1261, 1270-74 (1998).

${ }^{10}$ Hendricks, 521 U.S. at 358-59. See also Allen v. Illinois, 478 U.S. 364, 375 (1986) (upholding Illinois Sexually Dangerous Persons Act on reasoning that " $[t]$ he essence of federalism is that states must be free to develop a variety of solutions to problems and not be forced into a common, uniform mold' of the sort urged by petitioner') (citation omitted). 
departs from previous historic efforts oriented toward physical constraints: the use of sex offender community notification laws. ${ }^{11}$ Pursuant to these laws, sex offenders (typically upon release from prison) live out their lives beyond the walls of confinement, but they do so with the knowledge that not just the State-but also their fellow citizens-are aware of their criminal history and whereabouts in the community. ${ }^{12}$ While the practical efficacy of such regimes has been seriously questioned, ${ }^{13}$ not least for the sense of false security they perhaps foster among community members, ${ }^{14}$ registration and notification laws are in place virtually nationwide, including at the federal level, and are enormously popular with the public. ${ }^{15}$ Viewed in context, the

"See Roe v. Office of Adult Probation, 938 F. Supp. 1080, 1092 (D. Conn. 1996) (“ $[$ C]ommunity notification is intended ... to protect the public from devastating crimes. This goal is certainly one within the traditionally broad police powers of the State.") (footnote omitted).

Several states, including California, Florida, Georgia, and Montana, have also resorted to alternate means of non-incarcerative control of sex offenders-chemical castration. See CAL. PENAL CODE § 645 (West 1999); FLA. STAT. ANN. § 794.0235 (West 1997); GA. CODE ANN. § 42-944-2 (1997); MONT. CODE ANN. § 45-5-512 (1997). See generally Robert D. Miller, Forced Administration of Sex-Drive Reducing Medications to Sex Offenders: Treatment or Punishment?, 4 PsYCHOL. PUB. POL'Y \& L. 175 (1998). For incisive treatments of the larger social forces contributing to the modern proliferation of legislative measures designed to protect society from sexual harm, see Deborah W. Denno, Life Before the Modern Sex Offender Statules, 92 NW. U. L. REv. 1317 (1998); John Pratt, The Rise and Fall of Homophobia and Sexual Psychopath Legislation in Postwar Society, 4 PSYCHOL. PUB. POL'Y \& L. 25 (1998).

${ }^{12}$ In addition to having purported benefits in terms of increasing community awareness and vigilance, the laws are thought justified by both specific and general deterrence. See Doe v. Poritz, 662 A.2d 367, 389 (N.J. 1995) (reasoning that registration and notification "[1]aws not only protect against crime but deter it: both for the potential offender . . . as well as for those who might otherwise commit a first sex offense but for the potential impact...").

is See, e.g., James R. Acker \& Catherine Cerulli, When Answers Precede Questions: Megan's Laws' Uncertain Policy Consequences, 34 CRIM. L. BULI. 235, $246-49$ (1998) (surveying potential pitfalls, including: that offenders are made more likely to commit crimes due to the ostracism associated with notification; that offenders will "go underground" to avoid notification; and that prospects for rehabilitation are significantly diminished due to the highly stigmatizing effects of notification).

${ }^{14}$ See Brian J. Telpner, Note, Constructing Safe Communities: Megan's Laws and the Purposes of Punishment, 85 GEO. L.J. 2039, 2063 (1997) (describing how registration and notification can lead to overconfidence); see also Mike Allen, Girl's Slaying Exposes Limits of Connecticut 'Megan's Law", N.Y. TIMES, Aug. 28, 1998, at B1 (noting inadequacy of local registry in preventing murder of child victim).

In fact, the basic assumption that sex offenses are typically committed by strangers, an assumption which appears to drive notification laws, itself lacks empirical support, raising further concern over the creation of a false sense of security. See Bruce J. Winick, Sex Offender Laws in the 1990s: A Therapeutic Juisprudence Analysis, 4 PSYCHOL. PUB. POL. \& L. 505, 55455 (1998) (citing studies indicating that most sex offenses are perpetrated by family members and those already known to the victim).

${ }^{15}$ See generally Wayne A. Logan, A Study in "Actuarial Justice": Sex Offender Classification Practice and Procedure, 3 BUFF. CRIM. L. REV. (forthcoming 2000) (surveying proliferation of laws). 
laws represent a conspicuous example of what Professor Carol Steiker has referred to as the emerging "preventive state," whereby government acts not as a "punisher ... but rather as preventer of crime and disorder more generally," and seeks to "identify and neutralize dangerous individuals before they commit crimes by restricting their liberty in a variety of ways."16

Since their implementation in the early 1990s, sex offender registration and notification laws have been the subject of repeated constitutional challenges, almost all unsuccessful. Attacks based on the Cruel and Unusual Punishment, Double Jeopardy, and Ex Post Facto Clauses have usually met with defeat, on the reasoning that such laws do not impose "punishment" for constitutional purposes. ${ }^{17}$ Less common challenges, sounding in equal protection, ${ }^{18}$ the right to unrestricted travel, ${ }^{19}$ and the Fourth Amendment ${ }^{20}$ have been rejected as well. With these claims exhausted, sex offenders have now turned to another constitutional avenue: procedural due process. Despite the fact that registration and notification can have deleterious,

Indeed, President Clinton has announced the federal initiation of a nationwide registry, designed in his words to "keep track of [sex offenders] - not just in a single state, but wherever they go, wherever they move, so that parents and police have the warning they need to protect our children. Deadly criminals don't stay within state lines, so neither should law enforcement's tools to stop them." See Mary McCrory, Clinton Sets Tracking of Sex Offenders, BosTON GLOBE, Aug. 25,1996 , at A1. This nationalization, in lieu of the non-uniform state use of registration, is directed at the concern that sex offenders will gravitate to jurisdictions without such requirements. See Sheila Grissert, Law Keeps Sex Offenders in Public Eye, Times-PICAYUNE (NEw ORLEANS), Oct. 24, 1993, at B1 (quoting Louisiana parole administrator to the effect that the State's community notification law has discouraged paroled sex offenders from locating in Louisiana).

${ }^{16}$ Carol S. Steiker, Supreme Court Review Foreword: The Limits of the Preventive State, $88 \mathrm{~J}$. CRrM. L. \& CRIMINOLOGY 771, 774 (1998).

${ }^{17}$ For examples of unsuccessful eighth amendment claims, see Roe v. Farwell, 999 F. Supp. 174, 193 (D. Mass. 1998); Doe v. Kelley, 961 F. Supp. 1105, 1112 (W.D. Mich. 1997); State v. Scott, 961 P.2d 667, 676 (Kan. 1998); Doe v. Poritz, 662 A.2d 367, 405 (N.J. 1995).

For examples of unsuccessful ex post facto and double jeopardy claims, see Russell v. Gregoire, 124 F.3d 1079, 1093 (9th Cir. 1997), cert. denied, 118 S. Ct. 1191 (1998); Doe v. Pataki, 120 F.3d 1263, 1285 (2d Cir. 1997), cert. denied, 118 S. Ct. 1066 (1998); E.B. v. Verniero, 119 F.3d 1077,1105 (3d Cir. 1997), cert. denied, 118 S. Ct. 1039 (1998); Spencer v. O'Connor, 707 N.E.2d 1039, 1044 (Ind. Ct. App. 1999); Porit, 662 A.2d at 404-05; Snyder v. State, 912 P.2d 1127, 1132 (Wyo. 1996). But see State v. Myers, 923 P.2d 1024, 1043 (Kan. 1996) (notification violates ex post facto); State v. Calhoun, 669 So. 2d 1359, 1363 (La. Ct. App. 1996) (registration alone violates ex post facto).

${ }^{13}$ See, e.g., Artway v. Attorney Gen., 81 F.3d 1235, 1267-68 (3d Cir. 1996); Farwell, 999 F. Supp. at 195; State v. Zichko, 923 P.2d 966, 970 (Idaho 1996); Porit, 662 A.2d at 413; State v. Ward, 869 P.2d 1062, 1076-77 (Wash. 1994); Snyder, 912 P.2d at 1132.

${ }^{19}$ See, e.g., State v. Cameron, 916 P.2d 1183, 1186 (Ariz. Ct. App. 1996).

${ }^{20}$ See, e.g., Rise v. Oregon, 59 F.3d 1556, 1558 (9th Cir. 1995); Rowe v. Burton, 884 F. Supp. 1372, 1381 (D. Alaska 1994). 
life-long effects, not all jurisdictions afford due process protections to the broad variety of offenders targeted. Moreover, state and federal courts have reached differing results on the question of whether those subject to notification possess a "liberty interest" sufficient to compel due process protections, i.e., notice and an opportunity to be heard. ${ }^{21}$

This article examines the critical threshold question of whether sex offender registrants enjoy a protectible liberty interest relative to community notification, ${ }^{22}$ which threatens the disclosure of highly personal data, including offenders' criminal history and address information, and the State's attendant branding of offenders as citizens worthy of fear and disdain. ${ }^{23}$ After describing the various state and federal procedures in place to effectuate community notification, the article examines the Supreme Court's decisions in the areas of privacy and governmental stigmatization. In Part IV, the decisions of the several state and federal courts that have thus far addressed the liberty interest issue are discussed, followed by an analysis of the significant due process and fairness issues raised. Finally, in Part V, the article considers how the Supreme Court is likely to address the question of whether notification implicates a cogni-

${ }^{21}$ As the Supreme Court has stated: "[w]e examine procedural due process questions in two steps: the first asks whether there exists a liberty or property interest which has been interfered with by the State; the second examines whether the procedures attendant upon that deprivation were constitutionally sufficient." Kentucky Dep't of Corrections v. Thompson, 490 U.S. 454, 460 (1989). See also United States v. James Daniel Good Real Property, 510 U.S. 43, 53 (1993) ("The right to prior notice and a hearing is central to the Constitution's command of due process.").

${ }^{2}$ In line with the vast majority of state and federal courts concluding that no liberty interest is implicated relative to registration alone, the discussion here is limited principally to the procedural due process concerns associated with notification. See, e.g., Artway, 81 F.3d at 1268 (finding no liberty interest with respect to registration alone); Cutshall v. Sundquist, $980 \mathrm{~F}$. Supp. 928, 931 (M.D. Tenn. 1997) (same), rev'd on other grounds, 193 F.3d 466 (6th Cir. 1999); In re C.M., 578 N.W.2d 391, 396 n.4 (Minn. Ct. App. 1998) (same); Commonwealth v. Mountain, 711 A.2d 478, 478 ( $\mathrm{Pa}$. Super. Ct. 1998) (same). Cf. Doe v. Attorney Gen., 686 N.E.2d 1007, 1014 (Mass. 1997) ("It may or may not be that the requirement that the plaintiff appear at a local police station, register as a sex offender, and answer certain questions impermissibly violates his liberty and privacy interests.").

${ }^{23}$ Importantly, the focus here is only on the threshold question of whether a liberty interest is implicated, not the precise contours or extent of due process that should be afforded once such an interest is identified. This latter inquiry, itself easily the subject of an article of equal length, is addressed pursuant to the Supreme Court's test enunciated in Matthews v. Eldridge, which balances: (1) the significance of the jeopardized interest; (2) the risk of erroneous deprivation of that interest as a result of the extant procedures and the probable value of additional safeguards; and (3) the government's interest, including the administrative burden associated with additional procedural safeguards. 424 U.S. 319, 334-35 (1976). 
zable liberty interest, in light of the Court's relevant precedent and increasing predisposition to regard "liberty" in narrow terms, especially with respect to the liberties retained by those convicted of crimes.

\section{SEX OFFENDER REgistration AND Notification PROVISIONS NATIONWIDE}

As is now well-known, the New Jersey Legislature in 1994 enacted "Megan's Law," officially referred to as the Sex Offender Registration Act, in response to the brutal sexual assault and murder of seven-year-old Megan Kanka. ${ }^{24}$ Although New Jersey was not the first American jurisdiction to register sex offenders, ${ }^{25}$ Megan's Law served as a dramatic catalyst for the registration movement. ${ }^{26}$ Today, all fifty states, the District of Columbia, and the federal government impose some form of registration requirement on sex offenders, however defined. ${ }^{27}$ This proliferation of registration laws, in no small part, has also stemmed from the unsubtle influence of the federal government which, in 1994, required states to register and gather in-

${ }^{24}$ See N.J. StaT. ANN. \$ 2C-7 (West 1995).

${ }^{25}$ California apparently was the first state to implement a sex offender registry, doing so in 1947. See Elizabeth A. Pearson, Status and Latest Developments in Sex Offender Registration and Notification Laws, in NATIONAL CONFERENCE ON SEX OFFENDER REGISTRIES 45 (U.S. Bureau of Justice Statistics ed., 1998).

${ }^{26}$ Id. In 1996, Massachusetts became the last state to enact a registration law. See Doris Sue Wong, Weld Signs Bill Creating Sex-Offender Registry-Those Convicted Have to Register, BosTON GLOBE, Aug. 15, 1996, at B2.

Criminal registration laws more generally trace their U.S. origins back to at least the 1930s. See Note, Criminal Registration Ordinances: Police Control Over Potential Recidivists, 103 U. PA. L. Rev. 60, 61-64 (1954). In Lambert v. Califormio, the Supreme Court invalidated a Los Angeles ordinance that made it unlawful for "any convicted person" to fail to register with local authorities, reasoning that the provision violated due process in the absence of "actual knowledge of the duty to register or proof of the probability of such knowledge ...." 355 U.S. 225, 229 (1957). Lambert, although apt, is likely of little consequence relative to the contemporary wave of sex of fender registration laws. For instance, citing Lambert, the Ninth Circuit recently rejected the claim of a habeas petitioner who challenged his conviction for failing to register as a sex offender as required by California law. See McDonald v. Marin County Sheriff, No. 98-16144, 1999 WL 390991 (9th Cir. May 25, 1999). Although petitioner was not notified of the registration requirements at the time of sentencing, he "received actual notice of the registration requirements before he was released from prison and was therefore able to 'avoid the consequences of the law.'" Id. at *1 (citing Lambert, 355 U.S. at 229). The MaDonald court also rejected petitioner's claim, based on Robinson v. California, that the law in effect sought to "criminalize" his "status" as a sex offender; on the contrary, the court held, the law "properly criminalizes the act of failing to register." Id. at *2 (discussing Robinson v. California, 370 U.S. 660 (1962)).

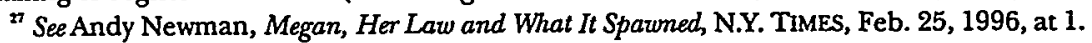


formation on sex offenders under threat of losing a portion of federal funds if they did not comply. ${ }^{28}$

Even more recently, jurisdictions in overwhelming numbers have enacted laws that allow public dissemination of registrant information, once again under federal threat. Although the 1994 federal legislation stated that jurisdictions "may release" collected registrant information, ${ }^{29}$ Congress in 1996 directed that state law enforcement "shall release relevant information that is necessary to protect the public" concerning registrants. ${ }^{30}$ Officially called the Jacob Wetterling Crimes Against Children and Sexually Violent Offender Registration Program, ${ }^{31}$ the federal law represents "a floor for state programs, not a ceiling,"32 relative to both the information that must be gathered ${ }^{33}$ and the types of offenders subject to registration. ${ }^{34}$

2s See 42 U.S.C. \$ 14071 (d) (1994).

see id. (stating that information "shall be treated as private data except that" it "may" be disclosed to law enforcement and government agencies for background checks, and that police "may release relevant information that is necessary to protect the public ..."). Washington State, in 1990, became the first jurisdiction to enact a sex offender "notification provision." See Pearson, supra note 25, at 45.

* See Megan's Law, Pub. L. No. 104145, § 2(d), 110, codified at 42 U.S.C. § 14071(e)(2) (1995 \& Supp. 1999). As the federal guidelines unequivocally state:

[A] State cannot comply with the Act by releasing registration information only to law enforcement agencies, to other governmental or non-governmental agencies or organizations, to prospective employers, or to the victims of registrants' offenses. States also cannot comply by having purely permissive or discretionary authority for officials to release registration information. Information must be released to members of the public as necessary to protect the public from registered offenders.

See Megan's Law; Final Guidelines for the Jacob Wetterling Crimes Against Children and Sexually Violent Offender Registration Act, as Amended, 64 Fed. Reg. 572, 581 (1999) [hereinafter Final Guidelines].

"See 42 U.S.C. $\$ 14071$ (1998) (emphasis added).

"See Final Guidelines, supra note 30, at 572.

s" Federal law, for instance, requires that registration information, at a minimum, include an offender's name, fingerprints, photo, and present address (which must remain updated). See 42 U.S.C. $\$ 14071$ (b) (1). The Guidelines suggest that States might also wish to obtain (1) information about a registrant's "expected employment" upon release from confinement and (2) "DNA samples ... to be typed and stored in state DNA databases." See Final Guidelines, supra note 30, at 579 .

${ }^{4}$ Federal law requires, at a minimum, that states register persons "convicted of a criminal offense against a victim who is a minor" and those "convicted of a sexually violent offense." See 42 U.S.C. § 14071 (a) (1) (A). The former category includes kidnapping and false imprisonment of a minor (by other than a parent), as well as an extensive array of sex-related offenses (including attempts). See id. \$1407i(a) (3) (A) (i)-(viii). The latter includes forms of aggravated and nonaggravated sexual abuse, as defined by federal law. See id. $\S 14071$ (a)(3)(B). See also Final Guidelines, supra note 30, at 577 (including "rape or rape-like offenses-i.e., non-consensual sexually assaultive crimes involving penetration-regardless of the age of the victim"). 
Therefore, the federal government has mandated that registrants' information be released, ${ }^{35}$ but has largely left to the states, consistent with "public safety purposes," the questions of (1) which offenders should be the target of disclosure; (2) the information gathered and the extent of disclosure; and (3) the standards and procedures, if any, appropriate to these determinations. ${ }^{36}$

${ }^{35}$ At present, jurisdictions use any (or some combination) of three methods of dissemination: (1) "public access," which requires community members to request information from a given jurisdiction's registry (which can exist in written or CD-ROM form, and at times can also be accessed by telephone "hot-line"); (2) Internet web-site access; and (3) affirmative community notification by law enforcement, which can involve the use of informational fliers and doorto-door visits by police. See DEVON B. ADAMS, U.S. BUREAU OF JUSTICE STATISTICS, SUMMARY OF STATE SEX OfFender REgistry Dissemination PROCEDUREs: UPDATE 1999 (1999) (describing variety of methods). In one jurisdiction, Louisiana, registrants themselves are required to effectuate notification. Among other statutory requirements, each registrant must:

[g]ive notice of the crime for which he was convicted, his name, and address to: (a) at least one person in every residence or business within a one mile radius in a rural area and a three square block area in an urban or suburban area of the address where the defendant will reside upon release ....

LA. REv. STAT. ANN. \$ 542(B)(1)(a) (West 1999). The sentencing court, in its discretion, can also require notification by means of "signs, handbills, bumper stickers, or clothing labeled to that effect." Id. \$542(B) (3).

Among the various strategies, the Internet possesses the greatest potential for widespread dissemination-even beyond state or local boundaries. Indeed, in California, where authorities primarily use a CD-ROM to effectuate notification, individuals have transcribed registrant information and instituted their own web sites containing registrant data. See Kathleen Ingley, Sex Offender Info Goes Online: Posting Seen as Powerful Tool, Menace, ARIZ. REPUBLIC, May 4, 1999, at A1, available in LEXIS, News Group File. Also, in California, it appears that local law enforcement are permitted to enlist the help of the news media in disseminating registrant information, on the statutory premise that police are to "advise the public." See Byron M. v. City of Whittier, 46 F. Supp. 2d 1037, 1042 (C.D. Cal. 1998).

${ }^{36}$ Final Guidelines, supra note 30 , at 582 . Federal law does specify heightened requirements for offenders deemed "sexually violent predators." See 42 U.S.C. \$ 14071 (a) (1)(B), (a) (2). A "sexual predator" is "a person who has been convicted of a sexually violent offense and who suffers from a mental abnormality or personality disorder that makes the person likely to engage in predatory sexually violent offenses." Id. $\S 14071$ (a)(3)(C). Unlike all other potential registrants, federal law makes such offenders alone subject to a judicial determination of their eligibility for registration and notification. See id. $\S 14071$ (a)(2)(A). The determination is to be "made by a court after considering the recommendation of a board composed of experts in the behavior and treatment of sex offenders, victims' rights advocates, and representatives of law enforcement agencies." Id. If the offender is categorized a "sexually violent predator," the state must also obtain "identifying factors, anticipated future residence, offense history, and documentation of any treatment received for the mental abnormality or personality disorder of the person." Id. $\$ 14071$ (b) (1) (B). "Predators" must also provide quarterly address verification (as opposed to the annual verification required of registrants more generally). Id. \$ 1407l (b) (3) (B). Finally, "predators" are subject to mandatory lifetime registration. Id. § 14071 (b) (6) (B) (iii). The Department of Justice, however, can waive the judicial determination requirement if a jurisdiction employs "alternative measures of comparable or greater effectiveness." Id. \$14071(a)(2).

Importantly, however, the Guidelines leave it to the states to formulate how and when such a determination will be sought as to a particular offender. See Final Guidelines, supra note 30, at 
Pursuant to the latitude afforded by Congress, the states now use a variety of methods to determine which offenders warrant registration and notification. One approach, which, in the words of the Federal Guidelines is "consistent with the requirements of the Act," entails "particularized risk assessments . . . with differing degrees of information release[d] based on the degree of risk." 38 A handful of jurisdictions, including Massachusetts, New Jersey, and New York, use such an approach. ${ }^{39}$ Under these regimes, the recidivism risk levels of offenders are assessed on the basis of specified criteria during a hearing before a court or a specially constituted board, with due process rights afforded to the offender. The evaluative outcome determines the extent, method, and duration of public notification experienced by offenders. For instance, only law enforcement might be notified of the presence of "low risk" offenders, while community entities at particular risk (e.g., schools or child care facilities) are notified of "medium risk" offenders, and the community as a whole is warned of "high risk" offenders.

On the other hand, nineteen states employ a compulsory approach, which requires that offenders satisfying statutory, offense-related criteria be subject to registration and notification, affording offenders no right to a prior hearing on the eligibility determination. ${ }^{41}$ Seven others leave it to the exclusive discretion

583 (stating that such a triggering event can result from the "judgment of prosecutors, or might provide that a determination of this question should be undertaken routinely when a person is convicted of a sexually violent offense .... ). Moreover, the determination can be made either at time of sentence imposition or just prior to release from custody. Id.

"Final Guidelines, supra note 30, at 582.

${ }^{*} I d$.

${ }^{3}$ See MASS. GeN. LAWS ANN. ch. 6, §§ 178D, 178K (West 1999); N.J. STAT. ANN. § 2C:7-1 (West 1997); N.Y. CORRECT. LAW \& 168 (McKinney 1999).

to See, e.g., MASS. GEN. LAWS ANN. ch. 6, § 178K (West 1999) (describing three-level notification system). In New York, all sex offenders convicted of specified offenses experience disclosure of their status as a convicted sex offender, the nature of their crime, and their specific risk level classification by means of a " 900 " number usable by any community member. See Doe v. Pataki, 3 F. Supp. 2d 456, 467 (S.D.N.Y. 1998). Level Two offenders experience identical exposure, but "any entity with vulnerable populations" can receive the registrant's "background information," a photograph, and approximate home address. Id. (citation omitted). Level Three offenders are subject to community-wide dissemination of their exact address, in addition to the aforementioned other information. Id. Furthermore, with respect to Level Two and Three registrants, entities "with vulnerable populations" can disseminate information received "at their discretion." Id.

1 See ALA. CODE § 15-20-21 (1999); ALASKa STaT. \$§ 18.65.087, 12.63 .010 (Michie 1999); CAL. PENAl Code $§ 290$ (West 1999); CONN. GEN. STAT. ANN. § 54-250 to -261(West Supp. 1999); DEL. CODE ANN. tit. 11, § 4121 (1999); 730 ILL. COMP. STAT. 150/2 to $-/ 12,152 / 105$ to - 
of local law enforcement, ${ }^{42}$ despite their presumptive lack of clinical expertise, ${ }^{43}$ to determine on an ex parte basis which statu- . torily eligible offenders pose the greatest community risk, and therefore warrant being subject to notification. Finally, in many states, due process is afforded only to a select group of statutorily specified offenders (e.g., "sexually violent predators"). ${ }^{44}$

The upshot of the present situation is that, although registrants face the acute public opprobrium, and manifold other negative consequences of notification, ${ }^{45}$ for periods of time

/130(West 1993 \& Supp. 1999); IND. CODE ANN. § 5-2-12-4 (West Supp. 1999); KAN. STAT. ANN. $\S 22-4902$ to 4909 (1999); MrCH. COMP. LAWS ANN. § 28.722 to .730 (West 1999); MISS. CODE ANN. § 45-39-1 to -19 (Supp. 1999); Mo. ANN. STAT. § 589.400 to .425 (West Supp. 1999); N.H. REv. STAT. ANN. § 651-B:1 to -B:9 (Supp. 1999); N.M. STAT. ANN. § 29-11A-2 to -7 (Michie 1997 \& Supp. 1999); OKLA. STAT. ANN. tit. 57, \$\$ 581-589 (West 1991 \& Supp. 2000); S.C. CODE ANN. $\S 23-3-400$ to -520 (Law Co-op. 1999); S.D. CoDIFIED LAwS § 22-22-31 to -41 (Michie 1999); TENN. CODE ANN. § 40-39-101 to -110 (1997 \& Supp. 1999); UTAH CODE ANN. § 77-27-21.5 (1999); VA. CODE ANN. § 19.2-298.1 to -298.4 (Michie 1995 \& Supp. 1999).

2 See Ariz. Rev. STAT. ANN. § 13-3825 (West Supp. 1999); HAW. REv. STAT. § 846E-1 to -9 (Michie 1998); ME. REV. STAT. ANN tit. 34A $\S 11121$ to -11144 (West Supp. 1999); NEB. REV. STAT. ANN. §§ 29-4005, 29-4013 (Michie Supp. 1999); N.D. CENT. CODE § 12.1-32-15 (1999); WASH. REV. CODE ANN. $\S 4.24 .550$ (3) (West Supp. 1999); WIS. STAT. ANN. $\$ 301.45$ to -.46 (1999).

${ }^{43}$ Recidivism risk assessments, even when made by experts, are notoriously inaccurate in finding false-positives. See, e.g., Eric S. Janus, The Use of Social Science and Medicine in Sex Offender Commitment, 23 NEW ENG. J. ON CRIM. \& CIV. CONFINEMENT 347, $372 \mathrm{n} .11$ (1997) (citing studies); Jenny A. Montana, An Ineffective Weapon in the Fight Against Child Sexual Abuse: New Jersey's Megan's Law, 3 J.L. \& POL'Y 569, 590 (1995) (noting that predictions of dangerousness result in falsepositives two-thirds of the time). See generally Robert J. McGrath, Sex-Offender Risk Assessment and Disposition Planning: A Review of Empirical and Clinical Findings, 35 INT'L J. OFFENDER THERAPY \& COMP. CRIMINOLOGY 328, 331-43 (1991) (providing exhaustive review of studies revealing the difficulty of assessing future dangerousness).

Even more fundamentally, there is widespread disagreement over whether, in fact, sex offenders as a criminal sub-population manifest higher recidivism rates than other criminal actors. See, e.g., David P. Bryden \& Roger C. Park, “Other Crimes" Evidence in Sex Offense Cases, 78 MiNN. L. REv. 529, 572-73 (1994) ("[N]o study has demonstrated that sex offenders have a consistently higher or lower recidivism rate than other major offenders . ..."); R. Karl Hanson \& Monique T. Bussière, Predicting Relapse: A Meta-Analysis of Sexual Offender Recidivism Studies, $66 \mathrm{~J}$. CONSULTING \& CLINICAL PSYCHOL. 348, 357 (1998) (concluding, based on meta-analysis of 61 follow-up studies, that only $13 \%$ of offenders committed new sex offenses within a 45 year monitoring period); Kirk Heilbrun, et al., Sexual Offending: Linking Assessment, Intervention, and Decision-Making, 4 PSYCHOL. PUB. POL'Y \& L. 138, 139 (1998) (noting that there is "little consensus in the literature").

" Seg e.g., FLA. STAT. ANN. § 775.21 (West Supp. 1999); GA. CodE ANN. § 42-1-12 (Harrison 1998 \& Supp. 1999); IDAHO CODE § 18-8312 to -8321 (Supp. 1999); LA. REv. STAT. ANN. \$\$ 541 to 542.1 (West 1999); MD. CODE ANN., CRIMES AND PuNISHMENIS, $§ 792$ (a) (Supp. 1999); N.C. GEN. STAT. \$ 14-208.20 (Supp. 1998). North Carolina, for instance, has a two-track system: the "Sex Offender and Public Protection Program" and the "Sexually Violent Predator Registration Program."

is Reports of suicides and acts of vigilantism as a consequence of community notification have become common in the news. See, e.g., Robert Hanley, Shots Fired at the House of a Rapist, N.Y. TIMES, June 17, 1998, at BI (vigilantism); Todd S. Purdum, Death of Sex Offender is Tied to Megan's Law, N.Y. TIMES, July 9, 1998, at A16 (suicide); Convicted Rapist Is Shot At, N.Y. TMMES, July 
ranging from ten years to life, ${ }^{46}$ most states fail to afford offenders due process protections before notification decisions are made. ${ }^{47}$

Recently, several courts have stepped into this vacuum and required states to afford basic due process rights before individual sex offenders are subjected to notification. For instance, in Massachusetts the Supreme Judicial Court, in the absence of a legislative requirement, has held that due process compels that a hearing be conducted even before "level-one" sex offenders (those posing the least risk) are subject to registration and notification. In Oregon, the State Supreme Court required the State to provide registrants notice and an opportunity to be heard prior to carrying out notification. ${ }^{49}$ And the Middle District of Alabama recently enjoined application of the Alabama Community Notification Act, ${ }^{50}$ which entails arguably the na-

1, 1998, at B1 (vigilantism); Suicide is Recalled as Maine Revisits Megan's Law, WASH. PoST, Feb. 17, 1998 , at A2 (suicide).

With public disclosure there also often come a litany of related practical difficulties, such as finding work and a place to live. See, e.g., John T. McQuiston, Sex Offender Is Suing His Neighbors Over Protests, N.Y. TIMES, June 20, 1997, at B1 (describing rallies staged to protest registrant's presence, the throwing of a brick through his car window, and harassing calls to his employer); Lisa Sink, Long After Release Date, Man Still Lives in Prisom, Millwaukee J. Sentinel, June 1, 1999, at 1 , available in LEXIS, News Group File (describing inability of registrant to find residence 15 months after date of mandatory release); Convicted Child Molester Loses Job, L.A. Dally NEwS, Jan. 16, 1997, at N10 (describing how registrant was forced from his job); Parents Protest to Ohest Molester from Community: Neighbors Collect Signatures on Petitions, SACRAMENTO BEE, July 8, 1997, at B3 (recounting neighborhood's efforts to drive out registrant). Cf. Henry Gottlieb, Fighting a Local Ban on Sex Criminals, NAT'L L.J., May 17, 1999, at A7 (discussing lawsuit filed by homeowner against homeowners' association bylaw that bars residency to registrants).

${ }^{45}$ See Alan R. Kabat, Comment, Scarlet Letter Sex Offender Databases and Community Notification: Sacrificing Person Privacy for a Symbol's Sake, 35 AM. CRIM. L. Rev. 333, 359-61 (1998) (providing state-by-state listing reflecting range from 10 years to lifetime registration). Furthermore, in every jurisdiction, criminal prosecution (at times felony) can ensue if registration information is not maintained and verified at intervals prescribed by law. See infra note 197 and accompanying text.

${ }^{47}$ Some twenty-nine states do permit registrants to petition for a rehearing of a notification determination, but after notification has occurred, on the basis of successful rehabilitation or lack of perceived dangerousness. See Kabat, supra note 46, at 343 .

4See Doe v. Attorney Gen., 686 N.E.2d 1007, 1013 (Mass. 1997). According to the court:

[I]t is contrary to the principle of fundamental fairness that underlies the concept of due process of law to deny the plaintiff a hearing at which the evidence might show that he is not a threat to children and other vulnerable persons whom the act seeks to protect and that disclosure is not needed ... The plaintiff is entitled to a hearing and a determination as to whether he must register under the act and, if so, whether sex offender information conceming him should be available on request.

Id. at 1014.

- See Noble v. Board of Parole and Post-Prison Supervision, 964 P.2d 990, 997 (Or. 1998).

${ }^{\text {so }}$ Doe v. Pryor, 61 F. Supp. 2d 1224 (M.D. Ala. 1999). 
tion's most aggressive notification regime, ${ }^{51}$ because the Act failed to afford a particular offender notice and a hearing prior to notification. ${ }^{52}$

The prevalent lack of due process protections in the notification determination looms as a major constitutional issue, one that is only now reaching the courts because of the recency of notification laws. State and federal courts, however, are divided on the due process question, reaching divergent results on the question of whether registrants possess a "liberty interest" sufficient to require due process. This lack of constitutional concern doubtless stems in large part from the unappealing status of the litigants pressing such claims. But it is also explained by the complex and uncertain body of federal constitutional law on the central questions of whether citizens possess a liberty interest as against governmental stigmatization and the disclosure of personal information. These questions are taken up next.

\section{Privacy, Reputation, AND the Bounds of Protectible LIBERTY INTERESTS}

It is a cardinal constitutional principle, embedded in no less than two amendments to the U.S. Constitution, ${ }^{53}$ that if the government desires to deprive any citizen of "life, liberty or property," at a minimum, notice and an opportunity to be heard must first be afforded. ${ }^{54}$ Despite the clarity of the command, the Supreme Court has charted a zig-zag course with respect to the precise interests deemed deserving of due process protection.

${ }^{31}$ ALA. CODE $\$ 15-20-20$ to -24 (1999). Notification occurs by means of a "flyer" that contains, inter alia, offense information, a photo, and the name and home address of the registrant. See id. § 15-20-21 (a) (2). Law enforcement is required to distribute the flyer by hand or regular mail, or by means of posting the flyer, placing it in a local newspaper, or making it available on the Internet or "other means available." Id. \$ 15-20-22(a). The geographic breadth of the notification varies by location. In Alabama's larger cities, notice is spread to all residences within 1,000 feet of the offender's residence and to all schools and childcare facilities within three miles. Id. $\$ 15-20-22$ (a) (2). In other areas, notice goes to all residences within 2,000 feet of the offender's residence and to all schools and childcare facilities within six miles. Id. \$ 15-2022(a) (3).

${ }^{52}$ Pryor, 61 F. Supp. 2d at 1225.

ss See U.S. CONST. amend. V ("[N] or shall any person . . . be deprived of life, liberty or property, without due process of law ...."); U.S. CONST. amend. XIV ("[N]or shall any State deprive any person of life, liberty, or property without due process of law ....").

${ }^{54}$ See Cleveland Bd. of Educ. v. Loudermill, 470 U.S. 532 (1985); Parratt v. Taylor, 451 U.S. 527 (1981); Goss v. Lopez, 419 U.S. 565 (1975); Fuentes v. Shevin, 407 U.S. 67 (1972). 
As Professor Laurence Tribe observes in his treatise, identification of protected "liberty" interests, in particular:

has been an evolving process punctuated by vague generalizations and declarations of broad overarching principles. Due process has been held to protect "those fundamental principles of liberty and justice which lie at the base of all our civil and political institutions," and to guarantee those procedures which are required for the "protection of ultimate decency in a civilized society. ${ }^{55}$

Notification laws, which disseminate highly personal and stigmatizing information to entire communities on the basis of perceived risk of sex offender recidivism, raise obvious concern over whether the "liberty" of sex offenders is jeopardized. As discussed next, however, the Supreme Court's relevant precedent fails to provide a clear-cut answer to the question of whether a cognizable liberty interest protects against disclosure of such information without prior notice and an opportunity to be heard on whether notification is appropriate and, if so, its extent.

\section{A. NONDISCLOSURE OF PERSONAL INFORMATION}

It is well established that the Constitution ensures a general right to informational privacy, which the Court has characterized as the "individual interest in avoiding disclosure of personal matters. ${ }^{, 56}$ However, while such a right indisputably exists, its contours have yet to be clearly delineated by the Court.

In Whalen $v$. Roe, for instance, the Court considered whether a New York law, requiring that personal physicians inform a State agency of the names of patients receiving certain drugs, violated the patients' rights to privacy. ${ }^{57}$ The Court concluded that the patients had a privacy right as to the medical information, but stated that no deprivation of liberty was threatened because the law contained strict security measures designed to

ss Laurence H. TRibe, AMERICAN ConstrTutional LAw \$ 10-8, at 678 (2d ed. 1988) (citations omitted) (quoting Hurtado v. California, 110 U.S. 516, 535 (1884) and Adamson v. California, 332 U.S. 46, 61 (1947) (Frankfurter, J., concurring)).

${ }^{\text {so }}$ See Whalen v. Roe, 429 U.S. 589, 598 n.23, 599-600 (1977). Additionally, individuals enjoy a privacy right against unwarranted governmental intrusion upon their capacity to make important decisions of an intimate or personal nature. See Roe v. Wade, 410 U.S. 113, 152-53 (1973). See generally Shields v. Burge, 874 F.2d 1201, 1209 (7th Cir. 1989) (referring to respective interests as the "confidentiality" and "autonomy" strands of the right of privacy).

${ }^{57}$ Whalem, 429 U.S. at 591-93. 
protect against unwarranted disclosure. ${ }^{58}$ Because the New York law involved only the accumulation, not disclosure, of sensitive personal information, the Whalen Court expressly reserved opinion on whether any constitutional concerns would be presented in relation to the "unwarranted disclosure of accumulated private data-whether intentional or unintentional . . ."

In two subsequent decisions the Court did address the issue of public disclosure. In 1989, the Court decided United States Department of Justice v. Reporters' Committee for Freedom of the Press, ${ }^{60}$ involving a request made pursuant to the Freedom of Information Act (FOIA) by journalists for the "rap-sheet" of a specified individual. $^{61}$ The government refused to release the information in the name of the individual's right to privacy. ${ }^{62}$ The Court agreed, concluding that FOIA created an expectation of privacy as to the assembled criminal history information contained in the "rap-sheet," despite the otherwise "public" nature of the information. According to the Court:

Although much rap-sheet information is a matter of public record, the availability and dissemination of the actual rap sheet to the public is limited. Arrests, indictments, convictions, and sentences are public events that are usually documented in public records .... [However], [the majority of] States place substantial restrictions on the availability of criminal history summaries even though individual events in those summaries are matters of public record. ${ }^{6}$

Although it found a privacy right to exist relative to the disclosure of such sensitive information, the Court was at pains to acknowledge the statutory nature of the claim before it, stating "[t] he question of the statutory meaning of privacy under the FOIA is, of course, not the same as the question ... [ [of] whether an individual's interest in privacy is protected by the Constitution."

ss Id. at 599 .

${ }^{39}$ Id. at 605-06. Justice Brennan, concurring, stated that such disclosure would violate the right to privacy, while Justice Stewart opined to the contrary. See id. at 606 (Brennan, J., concurring); id. (Stewart, J., concurring).

${ }^{\infty} 489$ U.S. 749 (1989).

"A "rap-sheet" typically contains the date of birth, physical description, and history of arrests, charges, convictions, and sentences of offenders. Id. at 752.

${ }^{62}$ Id. at 757-58.

"s Id. at 753 .

${ }^{\text {bi }}$ Id. at 762 n.13. 
Five years later, in United States Department of Defense v. Federal Labor Relations Authority, ${ }^{65}$ the Court addressed whether the disclosure of the home addresses of non-unionized federal employees, at the request of two labor unions, violated the employees' privacy rights arising under both the federal Privacy Act of 1974 and FOIA. ${ }^{66}$ Characterizing the public interest in disclosure as "negligible," weighed against the "not insubstantial" interest of the employees to keep their addresses private, the Court prohibited the compelled disclosure. ${ }^{67}$ The Court deemed insignificant the fact that the addresses themselves were otherwise publicly available by means of such sources as telephone directories and voter registration lists, stating: "[a]n individual's interest in controlling the dissemination of information regarding personal matters does not dissolve simply because that information may be available to the public in some form." This privacy interest is especially implicated, Justice Thomas reasoned for the majority, because disclosure of the employee addresses threatened unwarranted intrusions into the home (on the basis of unsolicited mailings, phone calls or visits), ${ }^{69}$ a domain "accorded special consideration in our Constitution, laws, and traditions."70

Taken together, the Court's decisions in the area of informational privacy establish that such a right exists and that the privacy expectation as to personal information is not wholly dissolved merely because the information is otherwise publicly available. As the Reporters' Committee Court stated in preventing compelled disclosure of an individual's rap-sheet, "[p]lainly

510 U.S. 490 (1994).

${ }^{\infty}$ Id. at 493-94 (citing 5 U.S.C. $\$ 552 \mathrm{a}$ (b) (2) (1988 ed. \& Supp. IV)).

${ }^{67}$ The Court expressly reserved opinion on the specific extent and nature of the employees' privacy interest in keeping their addresses confidential: "Because a very slight privacy interest would suffice to outweigh the relevant public interest, we need not be exact in our quantification of the privacy interest. It is enough for present purposes to observe that the employees' interest in nondisclosure is not insubstantial." Id. at 500.

${ }^{\text {cos Id. }}$.

${ }^{\infty}$ Id. at 501.

${ }^{\infty}$ Id. The Court added:

Moreover, when we consider that other parties, such as commercial advertisers and solicitors, must have the same access under FOIA as the unions to the employee address lists sought in this case, it is clear that the individual privacy interest that would be protected by nondisclosure is far from insignificant. Id. 
there is a vast difference between the public records that might be found after a diligent search of courthouse files, county archives, and local police stations throughout the country and a computerized summary located in a single clearinghouse of information." Similarly, although the home addresses of individuals are otherwise publicly available to those who affirmatively seek them out, the Court in Federal Labor Relations Authority made clear that because the home enjoys special constitutional privacy protection, public disclosure of addresses warrants special concern. ${ }^{72}$ At the same time, however, the Court's decisions seemingly leave unanswered whether a constitutional-as opposed to a statutory-right of privacy exists relative to the disclosure by the government of sensitive personal information. ${ }^{73}$

\section{B. PERSONAL REPUTATION}

Closely related to the issue of whether individuals have a protectible constitutional interest relative to the government's publication of embarrassing or sensitive facts, even if otherwise publicly available, is the question of whether there exists a liberty interest in avoiding governmental stigmatization or besmirchment of personal reputation. Once again, as with the right to informational privacy, while the Court has been clear that individuals possess some interest against unwarranted gov-

" United States Dep't of Justice v. Reporters' Comm. for Freedom of the Press, 489 U.S. 749, 763 (1989).

${ }_{27}$ Federal Labor Relations Auth., 510 U.S. at 501.

In Cox Broadcasting Comp. v. Cohn, the Court again touched upon the issue of public disclosure of otherwise private information. 420 U.S. 469 (1975). There, the Court invalidated a state statute that prohibited the disclosure of the names of rape victims, which was "truthful information contained in official court records open to public inspection." Id. at 494-95. However, in so doing the Court emphasized the important First Amendment interest in keeping government activity (e.g., judicial proceedings) open to public scrutiny. Id. at 495 . See also Florida Star v. B.J.F., 491 U.S. 524, 541 (1989) (holding that newspaper's publication of publicly released, lawfully obtained police report that identified rape victim did not unconstitutionally invade privacy).

${ }^{73}$ Compare E.B. v. Verniero, 119 F.3d 1077, 1103 n.23 (3d Cir. 1997) (noting that the Court has expressly reserved decision on the issue of any constitutional right in favor of nondisclosure) with Doe v. Wigginton, 21 F.3d 733, 740 (6th Cir. 1994) (noting that "the Constitution does not encompass a general right to nondisclosure of private information"). 
ernmental actions that harm personal reputation, ${ }^{74}$ the constitutional parameters of this interest remain elusive.

In 1971, the Court in Wisconsin $v$. Constantineau ${ }^{75}$ addressed the constitutional validity of a Wisconsin statute that permitted local officials, without notice or hearing, to post in liquor stores the names of those who engage in "excessive drinking," and to prohibit liquor sales to such persons. ${ }^{76}$ By a 6-3 vote, the Court condemned the "posting" on due process grounds, unequivocally holding that "where the State attaches 'a badge of infamy" to the citizen, due process comes into play."

Where a person's good name, reputation, honor, or integrity is at stake because of what the government is doing to him, notice and an opportunity to be heard are essential. "Posting" under the Wisconsin Act may to some be merely the mark of illness, to others it is a stigma, an official branding of the person. The label is a degrading one .... This appellee was not afforded a chance to defend herself. She may have been the victim of an official's caprice. Only when the whole proceedings leading to the pinning of an unsavory label on a person are aired can oppressive results be prevented.

Only five years later, in Paul v. Davis, ${ }^{79}$ the Court addressed the constitutionality of police distribution of "flyers" to eight

"See, e.g., Gertz v. Robert Welch, Inc., 418 U.S. 323, 341 (1974) ("[T]he individual's right to the protection of his own good name 'reflects no more than our basic concept of the essential dignity and worth of every human being - a concept at the root of any decent system of ordered liberty." ) (citation omitted); In re Winship, 397 U.S. 358, 363-64 (1970) ("[B]ecause of the certainty that [one found guilty of a crime] would be stigmatized by the conviction ... . a society that values the good name and freedom of every individual should not condemn a man for commission of a crime when there is reasonable doubt about his guilt."); Wieman v. Updegraff, 344 U.S. 183, 190-91 (1952) ("There can be no dispute about the consequences visited upon a person excluded from public employment on disloyalty grounds. In the view of the community, the stain is a deep one; indeed, it has become a badge of infamy.").

${ }^{73} 400$ U.S. 433 (1971).

${ }^{76}$ Id. at 434 .

"Id. at 437 (citation omitted).

${ }^{73}$ Id. Earlier in the opinion the majority stated: "It is significant that most of the provisions of the Bill of Rights are procedural, for it is procedure that marks much of the difference between rule by law and rule by fiat." $I d$. at 436 .

${ }^{7} 424$ U.S. 693 (1976).

In Board of Regents $v$. Roth, the Court addressed only in passing the relation between reputation and liberty. 408 U.S. 564 (1972). In Roth, an untenured university professor sued his employer when he was not rehired at the conclusion of his one-year appointment, alleging that "the failure of University officials to give him notice of any reason of nonretention and an opportunity for a hearing violated his right to procedural due process of law." Id. at 569. The Roth Court concluded that no liberty interest was implicated because the University made neither "any charge against him that might seriously damage his standing and associations in the community," nor "imposed on him a stigma or other disability that foreclosed his freedom to take advantage of other employment opportunities." Id. at 573. The Court hastened to add, how- 
hundred local businesses containing the names and photographs of "active shoplifters." Plaintiff, who had been arrested for shoplifting (but not convicted), sued under 42 U.S.C. $\S$ 1983, alleging that his due process rights were violated when he was so identified without first receiving notice and an opportunity to be heard. ${ }^{80}$ The Sixth Circuit upheld the claim, relying on Constantineau. ${ }^{81}$

In an opinion written by then-Justice Rehnquist, a fivemember ${ }^{82}$ majority reversed, characterizing the claim as alleging damage to "mere reputation," which in itself does not implicate "liberty." According to the majority, the plaintiff in effect alleged only that "the State may not publicize a record of an official act such as an arrest, ${ }^{, 84}$ which in itself is not actionable: "reputation alone, apart from some more tangible interest" is not an interest deserving of constitutional protection. ${ }^{85}$ The majority concluded that, if the "posting" was actionable as defamation, any remedy the plaintiff may have had lay with state tort law. ${ }^{86}$ In so deciding, the majority distinguished Constantineau, which it characterized as involving more than "mere defamation"; according to the Paul majority, the "posting" in Constantineau deprived the claimant of a "right previously held under state law-the right to purchase or obtain liquor in common with the rest of the citizenry."

The majority also summarily rejected Paul's claim that circulation of the flyer violated his right to privacy. ${ }^{88}$ Citing Roe $v$. Wade, ${ }^{89}$ and Palko v. Connecticut, ${ }^{90}$ Justice Rehnquist stated that the alleged substantive right before the Court fell outside the

ever, that had the University done either, a "different case" would have been presented. Id. at 573-74.

${ }^{\circ}$ Paul, 424 U.S. at 695-96. In fact, after circulation of the flyer the shoplifting charge against the plaintiff was dismissed. Id. at 696 .

${ }^{81}$ Id. at 697.

${ }^{82}$ Justice Stevens took no part in the consideration or decision of the case. Id. at 714 .

${ }^{23}$ Id. at 708-09.

st Id. at 713.

${ }^{25}$ Id. at 701.

${ }^{\infty}$ Id. at 712 .

${ }^{87}$ Id. at 708.

Id. at 712-13.

${ }^{89} 410$ U.S. 113 (1973).

${ }^{\infty} 302$ U.S. 319 (1937). 
"fundamental" guarantees protected by the Constitution-"matters relating to marriage, procreation, contraception, family relationships, and child rearing and education." ${ }^{91}$ The plaintiff's claim was "far afield from this line of decisions":

He claims constitutional protection against the disclosure of the fact of his arrest on a shoplifting charge. His claim is based, not upon any challenge to the State's ability to restrict his freedom of action in a sphere contended to be "private," but instead on a claim that the State may not publicize a record of official act such as an arrest. None of our substantive policy decisions hold this or anything like this, and we decline to enlarge them in this manner. ${ }^{92}$

Paul has been widely condemned as an unjustified departure from what appeared to be the unequivocal recognition in Constantineau of a "reputational" liberty interest against governmental stigmatization. ${ }^{93}$ As Henry Paul Monaghan commented some twenty years ago: "in a 'Constitution for a free people,' it is an unsettling conception of 'liberty' that protects an individual against state interference with his access to liquor but not with his reputation in the community." Nonetheless, the Paul "stigma-plus" test ${ }^{95}$ remains the law of the land. ${ }^{96}$ In-

^ Paul, 424 U.S. at 713.

IId.

ss According to Richard Pierce, the Court's characterization of Constantineau as reflecting anything less "was purely historical invention. Under Constantineau, any damage to an individual's reputation attributable to a government source constituted a deprivation of a protected liberty interest." Richard J. Pierce, Jr., The Due Process Counterrevolution of the 1990s?, 96 ColuM. L. REV. 1973, 1983-84 (1996) (footnote omitted). See also Barbara E. Armacost, Race and Reprutation: The Real Legacy of Paul v. Davis, 85 VA. L. REv. 569, 576 (1999) (criticizing Paul generally and calling decision an "astonishing reinterpretation of Constantineau ..."); Sheldon Gelman, "Life" and "Liberty": Their Original Meaning, Historical Antecedents, and Current Significance in the De bate Over Abortion Rights, 78 MINN. L. REv. 585, 696 (1994) ("If the meaning of words in the founding era matters, reputation deserves constitutional protection."); Henry P. Monaghan, of "Liberty" and "Property", 62 CORNELL L. REV. 405, 424 (1977) ("The Court's re-rationalization of the earlier cases is wholly startling to anyone familiar with those precedents. In many ways I find this Pauls most disturbing aspect."); David L. Shapiro, Mr. Justice Rehnquist: A Preliminary View, 90 HARV. L. REV. 293, 328 (1976) (finding it "simply impossible to reconcile the explication of procedural due process contained in Paul v. Davis with prior decisions ...").

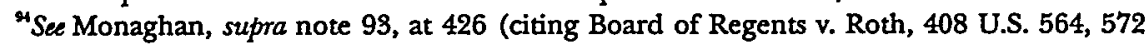
(1972)).

The Paul Court's apparent repudiation of Constantineau is all the more striking when one considers that the three dissenters in Constantineau themselves were concerned with abstention, not the question of whether a liberty interest was at stake. See Wisconsin v. Constantineau, 400 U.S. 433, 439-43 (1971) (Burger, C.J., dissenting) (joined by Blackmun, J.); id. at 443-45 (Black, J., dissenting) (joined by Blackmun, J.). test).

${ }^{25}$ See, e.g., Valmonte v. Bane, 18 F.3d 992, 999-1000 (2d Cir. 1994) (referring to "stigma-plus" 
deed, the Court's backpedaling from (although not outright reversal of) Constantineau was evidenced once again in 1991, when, in Siegert v. Gilley, ${ }^{97}$ the Court held that injury to reputation alone by the government does not implicate a liberty interest sufficient to trigger due process protections. ${ }^{98}$ In sum, as one constitutional treatise has noted, "it appears that a person's interest in his reputation may be totally unprotected by the due process clause. ${ }^{\text {99 }}$

As should be clear, the Court's decisions in the areas of informational privacy and governmental stigmatization evince a decided uncertainty. This lack of clarity notwithstanding, the decisions are now providing the essential analytic framework used by state and lower federal courts in their assessment of the emerging due process challenges to community notification laws.

\section{Due Process AND THE LIBERTY INTERESTS OF SEX OFFENDERS}

With alternate constitutional avenues having proved unavailing, ${ }^{100}$ sex offenders are now challenging state notification regimes on due process grounds-both substantive and procedural. To date, substantive due process claims drawn from the Supreme Court's uncertain informational privacy jurisprudence, discussed above, have been rejected by the courts. Even when notification is found to jeopardize a substantive right to privacy (usually because registrants' home addresses and places

\footnotetext{
${ }^{96}$ Whatever the constitutional merit of the Court's "stigma-plus" test, it is clear that the facts of Paul itself revealed something more than damage to "mere reputation." For instance, immediately after the flyer was circulated, plaintiff's supervisor at work summoned him to hear "his version of the events leading to his appearing in the flyer." Paul, 424 U.S. at 696. Subsequently, the supervisor warned that, although he would not then be fired, he "had best not find himself in a similar situation" in the future. Id. Moreover, as a result of the flyer, plaintiff's supervisor felt unable to assign him to any work involving a "mercantile establishment." Davis v. Paul, 505 F.2d 1180, 1184 (6th Cir. 1974), rev'd sub nom. Paul v. Davis, 424 U.S. 693 (1976). Finally, although the shoplifting charges against the plaintiff were eventually dismissed, five years after the flyer incident he reported that he was "broke, without employment, emotionally sick and in a state of anxiety." See The Supreme Court, 1975 Term, 90 HARV. L. REv. 58, 100-01 n.85 (1976).

${ }^{97} 500$ U.S. 226 (1991).

${ }^{\$} I d$ at 234.

${ }^{9}$ See RONALD D. ROTUNDA \& JOHN E. NOWAK, TREATISE ON CONSTITUTIONAL LAW § 17.4, at 67 (3d ed. 1999).

${ }^{100}$ See supra notes $17-20$ and accompanying text.
} 
of employment are disclosed), ${ }^{101}$ the right is deemed subsidiary to the overriding public interest thought served by making such information available. ${ }^{102}$ In other instances, no privacy right is recognized as a threshold constitutional matter, on the reasoning that registrants have a lessened expectation of privacy as to such "public" information, despite the fact that without notification the information is otherwise not nearly so readily available for community inspection and use. ${ }^{103}$ As discussed later, registrants have achieved greater, albeit not uniform, success by arguing that failure to provide notice and an opportunity to be heard prior to being subject to notification violates procedural due process, resorting to the much-maligned "stigma-plus" test enunciated in Paul v. Davis. ${ }^{104}$

\section{A. COURTS REFUSING TO FIND A LIBERTY INTEREST}

To date, the most influential decision rejecting a due process challenge is the Ninth Circuit's opinion in Russell v. Gregoire, ${ }^{105}$ which upheld the Washington State registration and notification scheme. In Washington, all sex offenders ${ }^{106}$ are required to provide the following information to the sheriff of their county of residence: name; address; date and place of birth; place of employment; crime of conviction and when and

${ }^{101}$ See, e.g., Paul P. v. Verniero, 170 F.3d 396, 404 (3d Cir. 1999); Doe v. Poritz, 662 A.2d 367, 408 (N.J. 1995).

${ }^{102}$ See, e.g., Paul P., 170 F.3d at 404 (characterizing state interest as "compelling"); Poritz, 662 A.2d at 412-13 (characterizing state interest as "legitimate and substantial"). Compare Paul $P$., 170 F.3d at 406 (Fullam, J., concurring) (questioning whether the "theoretical and 'feel-good" benefits of Megan's Law may in the long run, be overwhelmed by the law's negative consequences. Statutes enabling, even perhaps encouraging, vigilantism and similar harms, seem utterly at odds with constitutional values.").

${ }^{103}$ See, e.g., Russell v. Gregoire, 124 F.3d 1079, 1094 (9th Cir. 1997) ("[I]nformation collected and disseminated . . . is already fully available to the public and is not constitutionally protected."); E.B. v. Verniero, 119 F.3d 1077, 1103 (3d Cir. 1997) (failing to find that publication of 'registrants' convictions and findings of dangerousness implicate any interest of fundamental constitutional magnitude"); Rowe v. Burton, 884 F. Supp. 1372, 1384 (D. Alaska 1994) (holding that the right to privacy "does not attach to matters already within the public domain"); Paul $\mathbf{P}$. v. Verniero, 982 F. Supp. 961,968 (D. N.J. 1997) (holding that notification "do[es] not unconstitutionally implicate registrants' right to privacy"), affd, $170 \mathrm{~F} .3 \mathrm{~d} 396$ (3d Cir. 1999).

${ }^{104}$ See infra notes 139-63 and accompanying text.

${ }^{105} 124$ F.3d 1079 (9th Cir. 1997).

${ }^{106}$ Those subject to notification include offenders convicted of specified sex crimes, persons found not guilty of an eligible offense by reason of insanity, persons found incompetent to stand trial for an eligible offense and subsequently committed, persons committed as "sexual psychopaths," and persons committed as "sexually violent predators." Id. at 1082 (citing WASH. REV. CODE $§ 4.24 .550$ (3) (West 1988 \& Supp. 1997)). 
where it occurred; aliases used; social security number; photograph; and fingerprints. ${ }^{107}$ Prior to their release, an Offender Oversight Committee assesses on an ex parte basis offender risk levels based on information provided by the State Department of Corrections, and determines which of three classification levels (and hence scope and method of notification) is warranted. $^{108}$ Local law enforcement then independently reviews the designation and releases "relevant and necessary information" they deem "necessary for public protection." 109

Willie Russell and Johnny Stearns, both recently released sex offenders, were classified by the Committee as "Level Three" registrants, reserved for Washington's most feared offenders. As a result, a "standard notification form" was to be provided to: (1) government and law enforcement agencies; (2) schools within the federal census tract of the registrants' residence; (3) "Block Watch Captains" in the census tract and adjoining tracts; and (4) the local news media. ${ }^{110}$ The notification form included the registrants' picture, name, age, date of birth, as well as a summary of crime(s) committed, and general information relative to their home address and place of employment. ${ }^{11}$ The standard notification form also contained a "caveat" that threats, intimidation, or harassment of the registrant would "not be tolerated."

Subsequent to registering, Russell and Stearns sued to enjoin notification, alleging inter alia that Washington's law violated their substantive rights to privacy and procedural due process. The Western District of Washington denied their motions for injunctive relief, and notification was stayed pending appeal. $^{113}$

The Ninth Circuit upheld denial of the challenge on both bases. The court first rejected petitioners' argument that they enjoyed a substantive privacy right against governmental disclo-

\footnotetext{
${ }^{102}$ Id. (citing WASH. REv CODE § 9A.44.130 (West 1988 \& Supp. 1997)).

${ }^{100} I d$. at 1082.

${ }^{109}$ Id. See also WASH. REV. CODE $§ 4.24 .550$.

${ }^{110}$ Russell, 124 F.3d at 1082.

i" Id. at 1083.

${ }^{112}$ Id.

"Is Id.
} 
sure, stating that "any such right to privacy, to the extent it exists at all, would protect only personal information," such as the medical information at issue in Whalen $v$. Roe. ${ }^{\text {I14 }}$ The information subject to disclosure by notification in Washington was "already fully available to the public and is not constitutionally protected ... with the exception of the general vicinity of the offender's residence (which is published) and the offender's employer (which is collected but not released to the public). Neither of these two items are generally considered 'private." 115 Additionally, citing language in Paul $v$. Davis to the effect that liberty is not implicated "'apart from some more tangible interest[] such as employment," the court summarily concluded that no such additional harm was present, and that no deprivation therefore occurred. ${ }^{116}$

The court then turned to petitioners' procedural due process claim, based on Washington's failure to provide them with notice and an opportunity to be heard prior to their classification. Bootstrapping petitioners' failed substantive privacy claim to their procedural due process challenge, the court quickly dispensed with the challenge: "Since we have already rejected their privacy claims, we conclude that they have no liberty interest at stake, and we hence reject their due process claims."117

Russell was cited and followed by the District Court of Utah in Femedeer $v$. Haun. ${ }^{118}$ There the petitioner raised a procedural due process claim against Utah's notification provision, ${ }^{119}$ which makes available over the Internet without restriction and without prior notice or opportunity to be heard: the registrant's name; home address; physical description; type of personal vehicle(s) driven; any aliases; current photograph; crimes charged with and convicted of; and other offense-related information. ${ }^{120}$ Relying on Russell, the Femedeer court concluded that "[s]uch in-

\footnotetext{
"II Id. at 1094. See supra notes 56-59 and accompanying text.

${ }^{115}$ Russell, 124 F.3d at 1094 (citation omitted).

${ }^{116}$ Id. (citing Paul v. Davis, 424 U.S. 693, 701 (1976)).

"in Id.

"18 35 F. Supp. 2d 852 (D. Utah 1999).

"Id. at 855 . Petitioner also raised ex post facto, double jeopardy, and bill of attainder claims, all denied by the court because the Utah scheme was deemed non-punitive. Id. at 859 .

${ }^{120} I d$. at 860-61.
} 
formation is not considered private .... [It] 'is already fully available to the public and is not constitutionally protected.' ... Because Plaintiff cannot establish that disclosure impairs a constitutionally-protected interest, he cannot establish a cognizable injury to his reputation.",21

Identical results were achieved by federal district courts in Michigan. In Doe v. Kelley, ${ }^{122}$ the Western District of Michigan addressed a challenge to the State's compulsory registration and notification provision, which makes available upon request each registrant's name, home address, physical description, date of birth, and offense-related information. ${ }^{123}$ The court summarily denied the petitioners' claims for injunctive relief due to lack of any privacy right, refusing to find a protectible interest in "preventing compilation and dissemination of truthful information that is already, albeit less conveniently, a matter of public record." ${ }^{124}$

The Eastern District of Michigan in Lanni v. Engler ${ }^{125}$ denied another procedural due process claim to the Michigan notification law, using strikingly similar language. ${ }^{126}$ Even if a protectible interest against disclosure did exist, the Lanni court reasoned, it would be of no moment because the petitioner failed to demonstrate how notice and a hearing would serve such an interest, given that Michigan requires all statutorily eligible sex offenders to register and be subject to notification. ${ }^{127}$ Because "a hearing would serve no purpose," the challenge was "little more than an attack on the legislature's decision to subject sex offenders to registration and community notification. ${ }^{, 28}$ Nor, as a fundamental matter, did notification violate any privacy interest:

In this case, the information made public by the Act is already a matter of public record, to which no privacy rights attach. Therefore, plaintiff has failed to demonstrate the existence of a legitimate privacy

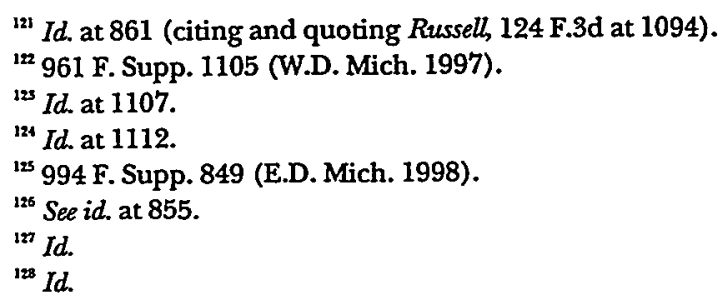


interest in preventing compilation and dissemination of truthful information that is already, albeit less conveniently, available as a matter of public record.

In People v. Logan ${ }^{130}$ the Illinois Court of Appeals, citing Lanni, rejected a due process challenge to the Illinois registration and notification regime, which likewise provides neither notice nor opportunity to be heard prior to notification. ${ }^{131}$ According to the Logan court, "the Registration Act merely compiles truthful, public information, and the Notification Law makes this information more readily available. Any injury to the defendant's reputation is a result of his underlying conviction of a sex offense." ${ }^{\text {132 }}$ Moreover, as in Lanni, because Illinois law subjects all sex offenders covered by the Act to notification, "law enforcement authorities have no discretion to determine which offenders would be subject to public dissemination. Thus, a hearing would serve no purpose.",133

Finally, in Cutshall v. Sundquist, ${ }^{134}$ the Sixth Circuit overturned a lower court's enjoinment of the Tennessee notification law, which allows law enforcement to "release relevant information deemed necessary to protect the public concerning a specific sexual offender who is required to register," without prior benefit of due process. ${ }^{135}$ The Sixth Circuit justified its rejection of Cutshall's procedural due process claim on two bases. First, seemingly presuming the existence of "stigma," as required by Paul, the court failed to find a "plus" in the form of alleged loss of and right to pursue employment, insofar as the Tennessee law did not expressly “infringe[] upon Cutshall's ability to seek,

${ }^{229} I d$. at 856 . Even more recently, the Eastern District rejected an identical claim using similar language:

The Court fails to discern how plaintiffs can claim deprivation of a liberty interest resulting from dissemination of information already the subject of public record ... [P]laintiffs have cited no authority for the proposition that the magnitude of dissemination, in and of itself, is sufficient to trigger a deprivation of a liberty interest.

Akella v. Michigan Dept. of State Police, 67 F. Supp. 2d 716, 729 (E.D. Mich. 1999).

130705 N.E.2d 152 (Ill. App. Ct. 1998).

is1 Id. at 160-61 (citing Lanni, 994 F. Supp. at 855).

is Id. (citing Lanni, 994 F. Supp. at 855).

1ss Id. at 161 (citing Lanni, 994 F. Supp. at 855).

19 193 F.3d 466 (6th Cir. 1999).

${ }^{15}$ Id. at 471 (citing TENN. CODE $\$ 40-39-106$ (c) (1994)). Notification can ensue by written notice, "electronic transmission," or "on-line access to registration information." See TENN. CODE $§ 40-39-106$ (d). 
obtain, and maintain a job."136 Next, the court concluded that the requisite "plus" was lacking on the basis of any alleged violation of a privacy interest, narrowly construing the Supreme Court's decision in Reporters' Committee. ${ }^{137}$ In short, the court concluded:

Gutshall has failed to establish that the Act infringes any constitutionally protected liberty or property interests in employment or privacy .... . Without the "plus" factor of employment or privacy, Cutshall has failed to satisfy the stigma-plus test of Paul. Therefore, he is not entitled to any procedural protections under the Due Process Clause.

Taken together, the courts failing to find a protectible liberty interest evince a heavy reliance on the question of whether registrants enjoy a "reasonable expectation of privacy" with regard to notification information. They categorically find that no such protectible expectation exists, drawing support from the Supreme Court's cases that have failed to enunciate an express constitutional right against nondisclosure. To these courts it does not matter that the information itself is only "public" in a technical sense (i.e., in telephone directories and remote criminal information databases), and is otherwise unavailable in the consolidated, user-friendly form permitted by registries. Importantly, also, these courts then apply this substantive result to the procedural analysis, thereby concluding that notification does not implicate a liberty interest sufficient to warrant due process protection when none otherwise statutorily exists.

\section{B. COURTS FINDING A LIBERTY INTEREST}

In the alternative, courts applying the "stigma-plus" test of Paul v. Davis ${ }^{139}$ have been much more inclined to find that a lib-

${ }^{136}$ Cutshall, 193 F.3d at 480.

${ }^{137}$ Id. at 481 (citing and discussing United States Dept. of Justice v. Reporters Comm. for Freedom of the Press, 489 U.S. 749, 751-56 (1989)).

${ }^{138}$ Id. at 482 .

In dissent, Judge Nathaniel Jones strongly condemned the majority's refusal to find a due process violation. According to Judge Jones:

The need to hold a due process hearing is made more acute by the fact that the Tennessee Act views all sex offenders the same, regardless of the severity of their crimes(s) .... Because the Tennessee Act forgoes such categorization, a due process hearing is of utmost importance, especially in the case of sex offenders whose crimes are less severe; the harm to them, should inaccurate disclosure to the public occur, would be great indeed.

${ }^{139} 424$ U.S. 693 (1976). See supra notes 79-96 and accompanying text. 
erty interest is jeopardized by notification. In Paul, the Court established that "reputation alone, apart from some more tangible interest such as employment, is [not] either 'liberty' or 'property' by itself sufficient to invoke the procedural protection of the Due Process Clause."140 Rather, the government must "alter 'a right or status previously recognized by state law,' for it is that 'alteration, officially removing the interest from the recognition [and protection] previously afforded by the State, which [the Court has] found sufficient" to trigger due process. ${ }^{141}$ In other words, it takes "harm to reputation in addition to some other impediment, to establish a constitutional deprivation." 142

As a threshold matter, all courts applying the "stigma-plus" test readily conclude that notification has negative effects on reputation. Like the accused "active shoplifter" in Paul, sex offenders subject to community notification suffer the infamy associated with being labeled in a derogatory manner by the State. ${ }^{143}$ Moreover, although registrants have already suffered reputational harm because of their public prosecution and conviction for a sex offense, notification entails a more acute and sustained harm. Offenders are consciously labeled by the government such things as "repetitive" and "compulsive"144 criminals with an especially "high risk" of re-offending," and, depending on applicable law, can suffer this public ignominy

${ }^{1+0}$ Paul, 424 U.S. at 701.

14l W.P. v. Poritz, 931 F. Supp. 1199, 1219 (D. N.J. 1996) (citations omitted), rev'd on other grounds, E.B. v. Verniero, 119 F.3d 1077 (3d Cir. 1997).

${ }^{112}$ Doe v. Pataki, 3 F. Supp. 2d 456, 467 (S.D.N.Y. 1998).

is See, e.g., id. at 468 (" [T] tion contemplated by the [New York law] to the community at large is potentially harmful to plaintiffs' personal reputations."); Doe v. Poritz, 662 A.2d 367, 419 (N.J. 1995) ("[Public notification] would expose plaintiff to public opprobrium, not only by identifying him as a sex offender but also labeling him as potentially currently dangerous, and thereby undermining his reputation and standing in the community.").

${ }^{1+4}$ See, e.g., Porits, 662 A.2d at 420.

is See, e.g., ARK. CODE ANN. § 12-12-902 (Michie 1999) ("The General Assembly finds that sex offenders pose a high risk of reoffending after release from custody ...."); NEB. REV. STAT. § 294002 (Supp. 1999) ("The Legislature finds that sex offenders present a high risk to commit repeat offenses."); N.C. GEN. STAT. § 14208.5 (1999) ("The General Assembly recognizes that sex offenders often pose a high risk of engaging in sex offenses even after being released . ..."); S.C. CODE ANN. § 23-3-400 (Law Co-op. 1999) ("Statistics show that sex offenders often pose a high risk of re-offending."). 
well past the end of their prison sentence, and, indeed, for the rest of their lives. ${ }^{146}$

The "plus" requirement of Paul, however, has received more diverse judicial interpretation. Although it made no express reference to Paul or the "stigma-plus" test, the Western District of Michigan in Doe v. Kelley, ${ }^{147}$ discussed above, failed to find a protectible liberty interest relative to Michigan's notification provision. ${ }^{148}$ According to the Kelley court, the law:

does nothing more than compile truthful, public information and make it available. To the extent public use of such information may result in damage to plaintiffs' reputation or may destabilize their employment and other community relations, such effects are purely speculative on the present record and, in any event, would appear to flow most directly from plaintiffs' own convicted misconduct and from private citizens' reactions thereto, and only tangentially from state action.

Likewise, as discussed above, the Sixth Circuit in Cutshall refused to find that Tennessee's notification law satisfied the "plus" standard. ${ }^{150}$

All other courts employing the "plus" test with respect to notification, however, have found it satisfied, with several decisions conceiving the privacy loss associated with notification itself as a "plus" sufficient to trigger due process. Perhaps most prominent among these is the New Jersey Supreme Court's 1995 decision in Doe v. Poritz. ${ }^{151}$ In Poritz, the court concluded that notification implicated protectible liberty interests in reputation and privacy for due process purposes, ${ }^{152}$ despite having first concluded that any fundamental substantive right of privacy was "substantially outweigh [ed]" by the State's interest in public disclosure. ${ }^{153}$ According to Poritz, "[t]he harm to plaintiff's

${ }^{146}$ See supra note 46.

${ }^{147} 961$ F. Supp. 1105 (W.D. Mich. 1997).

${ }^{1+3} I d$. at 1112. See also supra notes $122-24$ and accompanying text.

${ }^{1 * 9}$ Kelley, 961 F. Supp. 2d at 1112.

${ }^{150}$ Cutshall v. Sundquist, 193 F.3d 466, 482 (6th Cir. 1999).

131662 A.2d 367 (N.J. 1995).

${ }^{132} I d$. at 411 .

${ }^{13 s}$ Id. at 411,417 ("We deal here not the question of substantive constitutional deprivation, for we have held that there is none.").

In its substantive analysis, the Poritz court singled out for special concern that the registrant's home address would be divulged. Id. at 408 ("We believe that public disclosure of plaintiff's home address does implicate privacy interests."). At the same time, the court made clear its concern for the overall scope of information subject to disclosure: "the issue here is not whether 
reputation, when coupled with the incursion on his right to privacy, although justified by the compelling state interest, constitutes a protectible interest." ${ }^{254}$ Other courts have likewise deemed the privacy loss attending notification a sufficient "plus" to warrant due process protection. ${ }^{155}$

The loss or foreclosure of employment has also been identified as a sufficient additional "plus," in contrast to the Sixth Gircuit decision in Cutshall. Judge Myron Thompson of the Middle District of Alabama, for instance, recently addressed Alabama's State Community Notification Act, which, without providing due process, permits widespread notification on "criminal sex offenders." 156 After first identifying several colorable "plus" factors that served to deprive registrants of "rights previously held under State Law" (including provisions of the Act that preclude the right to change residences without first notifying the government, limit residence and work locations, and bar the right to legally change one's name), ${ }^{157}$ Judge Thompson focused on the non-statutory limits on registrants' freedom to pursue employment. There could be "little doubt" that prospective employers:

will think twice before doing business with an individual deemed to be a likely recidivist and a danger to the community, and, because the Act allows government officials to notify communities through the local media and the Internet, it is likely that at least some of those prospective business partners will become aware of the State's warning. To the extent that such opportunities are foreclosed, the plaintiff will have satisfied the "plus" of the stigma-plus test.

plaintiff has a privacy interest in his address, but whether the inclusion of plaintiffs address, along with other information, implicates any privacy interest." Id. at 409 . "In this case, where as a result of the information disclosed under the Notification Law, plaintiff may be exposed to uninvited harassment, we conclude that disclosure of plaintiff's home address, particularly when coupled with the other information disclosed, implicates a privacy interest." Id. In the end, however, the court characterized the interest against nondisclosure as "only a most limited expectation of privacy," insufficient in relative terms to allege a successful substantive due process violation. Id. at 411 .

${ }^{154} I d$. at 419.

iss See Doe v. Pryor, 61 F. Supp. 2d 1224, 1231 (M.D. Ala. 1999); Roe v. Farwell, 999 F. Supp. 174, 196-97 (D. Mass. 1998). See also Cutshall v. Sundquist, 980 F. Supp. 928, 932 (M.D. Tenn. 1997), rev'd on other grounds, 193 F.3d 466 (6th Cir. 1999).

${ }^{136}$ Pryor, 61 F. Supp. 2d at 1225. The Act is discussed supra note 51.

${ }^{157}$ Pryor, 61 F. Supp. 2d at 1281.

${ }^{138} \mathrm{Id}$. at 1232. Judge Thompson identified the deprivation of a "legitimate privacy interest in [plaintiff's] home address" as yet another non-statutory "plus." Id. 
Threat to future, not merely present, employment has been deemed a sufficient "plus" by the District of New Jersey as well. ${ }^{159}$

In Doe v. Pataki, ${ }^{160}$ the Southern District of New York deemed a sufficient "plus" the potentially life-long legal requirement for registrants to maintain and update their registry information with the government. Noting that any failure on the part of sex offenders to timely register risked exposure to criminal prosecution, the court stated that:

there can be no genuine dispute that registration alters the legal status of all convicted sex offenders subject to the Act.... These requirements obviously encroach on the liberty of convicted sex offenders, and, therefore, they suffer a tangible impairment of a right in addition to mere harm to reputation.

Perhaps the most expansive finding of "plus" is reflected in the opinion of the Supreme Judicial Court of Massachusetts which found a protectible interest to arise in the context of "Level 1" classification, entailing the Commonwealth's least invasive form of notification:

The combination of the following circumstances persuades us that plaintiff has a liberty and privacy interest protected by the Constitution that entitles him to due process: (1) the requirement that he register with local police; (2) the disclosure of accumulated personal information on request; (3) the possible harm to his earning capacity; (4) the harm to his reputation; and, most important, (5) the statutory branding of him as public danger, a sex offender. That statutory classification implicitly announces that, in the eyes of the State, the plaintiff presents a risk of committing a sex offense.

${ }^{139}$ W.P. v. Poritz, 931 F. Supp. 1199, 1219 (D. N.J. 1996) (noting that "stigma-plus" can be established "by coupling the reputational damage with the loss of employment opportunities ...") (footnote omitted).

${ }^{100} 3$ F. Supp. 2d 456 (S.D.N.Y. 1998).

${ }^{165} \mathrm{Id}$. at 468. See also W.P., 931 F. Supp. at 1219 (noting that "stigma-plus" can be established "by coupling the reputational damage with the loss of employment opportunities or, more directly, the continuing legal status as a registrant and the duties imposed as a result") (footnote omitted).

${ }^{102}$ Doe v. Attorney Gen., 686 N.E.2d 1007, 1013 (Mass. 1997). See also Doe v. Attorney Gen., 715 N.E.2d 37, $44-45$ (Mass. 1999) (holding that due process requires "individualized" hearing as precondition of registration and notification).

Recently, the Supreme Court of Oregon embraced an only slightly less expansive view, finding that in addition to the "obvious reputational interest that is at stake," there exists "an interest in avoiding the social ostracism, loss of employment opportunities, and significant likelihood of verbal and, perhaps, even physical harassment likely to follow from designation." Noble v. Board of Parole \& Post-Prison Supervision, 964 P.2d 990, 995-96 (Or. 1998). 
Finally, as the Minnesota Court of Appeals recently held, the statutory provision of immunity to governmental officials in relation to the execution of their notification duties can serve to deprive registrants of a previously existing right, sufficient to satisfy the "plus" requirement. ${ }^{163}$

\section{ANALYSIS}

The opinions in the two categories discussed above are noteworthy not just for their divergent results, but also for their distinct analytic approaches. To date, all courts rejecting procedural due process challenges to notification have done so because they discern no protectible privacy interest to be at stake. ${ }^{164}$ This approach, however, conflates substantive and procedural due process analysis, ${ }^{165}$ a perhaps predictable confusion because both species of due process regard the existence of a protectible interest as a threshold requirement. ${ }^{166}$ However, as

iss See In re C.M., 578 N.W.2d 391, 397-98 (Minn. Ct. App. 1998) (construing Remedies Clause of Minnesota Constitution, which provides that "[e]very person is entitled to a certain remedy in the laws for all injuries or wrongs which he may receive to his person ... or character" MiNN. CONST. art. I § 8.). The federal Jacob Wetterling Act and at least thirty states provide immunity for "good faith" conduct in relation to registration and notification. See Stephen $R$. McAllister, Megan's Laws: Wise Public Policy or Ill-Considered Public Folly?, 7 KAN. J.L. \& PUB. POL'Y 1,18 (1998).

${ }^{16}$ See supra notes $105-38$ and accompanying text.

${ }^{16 s}$ See ROTUNDA \& NoWAK, supra note 99, §§ 14.6, 14.7, 17.4 (surveying distinctions). See also Henry Paul Monaghan, State Law Wrongs, State Law Remedies, and the Fourteenth Amendment, 86 COLUM. L. REV. 979, 980 n.18 (1986) ("[T] he state must make a two-fold justification for injuries that it inflicts: procedural-the harm may be imposed only in the context of certain procedural safeguards-and substantive-the harm must be based on an adequate reason.").

The Supreme Court itself has been at pains to delineate the two distinct modes of constitutional inquiry: "The point is straightforward: the Due Process Clause provides that certain substantive rights-life, liberty, and property-cannot be deprived except pursuant to constitutionally adequate procedures. The categories of substance and procedure are distinct. Were the rule otherwise, the Clause would be reduced to a mere tautology." Cleveland Bd. of Educ. v. Loudermill, 470 U.S. 543, 546 (1985).

${ }^{166}$ See Paul v. Davis, 424 U.S. 693, 735 n.18 (1996) (Brennan, J., dissenting) ("[P]rivacy notions appear to be inextricably interwoven with the considerations which require that a State not single out an individual for punishment outside the judicial process."); ROTUNDA \& NOWAK, stpra note $99, \S 17.4$, at 28 ("The concept of liberty in the due process clauses is also the basis for the 'substantive due process' requirement that legislation must relate to a legitimate end of government."). As Professor Tribe observes in his treatise:

Including particular activities within the constitutional definition of "liberty" or "property" is not, of course, the equivalent of granting those activities total immunity from government regulation or deprivation. Nevertheless, such inclusion usually implies a burden of justification for every substantive curtailment of the interest in question, and always implies constitutional recognition of a procedural right to be heard even when a concededly valid government rule infringing that interest is enforced. 
several courts have held, ${ }^{167}$ and as discussed at greater length next, this redundancy does not justify the failure to find a protectible interest in the form of privacy for purposes of the "plus" criterion. Furthermore, there are sound reasons to conclude that the consequences of community notification amply satisfy the Paul "stigma-plus" test more generally.

\section{Notification and Its Impact on Privacy}

Despite the Supreme Court's ambiguous stance with regard to informational privacy, ${ }^{168}$ and Paul's express holding that the constitutional right to privacy does not prevent disclosure of "a record of an official act such as an arrest," tent of informational disclosure entailed in notification compels a judicial finding of a protectible interest.

Most fundamentally, the mere fact that an offender's criminal history is "public" in a technical sense, in no way resolves the constitutional question. As the Supreme Court stated with respect to the information gathered in the "rap-sheet" deemed protectible in Reporters' Committee, "[p]lainly there is a vast difference between the public records that might be found after a diligent search" of local police files, and the "summary located in a single clearinghouse of information," notification laws. In dismissing what it called respondents' "cramped notion of personal privacy," the Reporters' Committee Court stated "the fact that an event is not wholly private does not mean that an individual has no interest in limiting disclosure or dissemination of the information." ${ }^{171}$ Notification, as the Supreme Court of New Jersey has observed, similarly "links various bits of information-name, appearance, address and crime-that otherwise might remain unconnected." ${ }^{\text {172 }}$

TRIBE, supra note $55, \S 10-8$, at 682 (emphasis added) (footnote omitted).

${ }^{167}$ See, e.g., Roe v. Farwell, 999 F. Supp. 194, 196-97 (D. Mass. 1998) (finding privacy and liberty right); Doe v. Poritz, 662 A.2d 367, 419 (N.J. 1995) (same).

${ }^{168}$ See supra notes $56-73$ and accompanying text.

${ }^{169}$ Paul 424 U.S. at 713.

${ }^{170}$ United States Dep't of Justice v. Reporters' Comm. for Freedom of the Press, 489 U.S. 749,763 (1989).

${ }^{17}$ Id. at $763,770$.

${ }^{172}$ Poritz, 662 A.2d at 411 . 
However public any of those individual pieces of information may be, were it not for the Notification Law, those connections might never be made .... Those convicted of crime may have no cognizable privacy interest in the fact of their conviction, but the Notification Law, given the compilation and dissemination of information, nonetheless implicates a privacy interest. The interests in privacy may fade when the information is a matter of public record, but they are not non-existent. ${ }^{17}$

In addition to being distinctive for concentrating such information, and making it more readily available, notification laws are unique because the information they commonly disclose is of a far more sensitive, less public nature than otherwise publicly available. In particular, in addition to requiring sex offenders to provide offense information and a photograph, information publicly disclosed with impunity in Paul, ${ }^{174}$ states disseminate a broad array of other information including, most significantly, home and work address information. ${ }^{175}$ Address information, in particular, has been singled out for special concern by the courts. The Third Circuit, for instance, very recently dismissed the argument that privacy is vitiated by the mere fact that addresses are typically reposed in publicly available telephone directories. Acknowledging the "general understanding that home addresses are entitled to some privacy protection, whether or not so required by a statute," in Paul P. v. Vermiero supported its inference with the recogni-

${ }^{17 s}$ Id. The District of New Jersey has also singled out for constitutional significance the unprecedented form in which notification information is packaged and made available:

Megan's Law goes well beyond all previous provisions for public access to an individual's criminal history. Indeed, unlike previous access provisions, registration and public notification ensure that, rather than lying potentially dormant in a courthouse record room, a sex offender's former mischief-whether habitual or once-off-shall remain with him for life, as long as he remains a resident of New Jersey.

Artway v. Attorney Gen., 876 F. Supp. 666, 689 (D.N.J. 1995), affd, 81 F.3d 1235 (3d Cir. 1996).

${ }^{174}$ See supra notes 79-92 and accompanying text.

${ }^{173}$ See, e.g., AIA. CODE $\$ 15-20-21$ (3) (1998) (home address, physical description, photo); ALASKA STAT. $\$ 18.65 .087$ (b) (Michie 1999) (home and work address, date of birth, photo); HAW. REV. STAT. ANN. § 846E-3 (Michie 1998) (home and work address, photo, and personal vehicle information); KAN. STAT. ANN. § $22-4907$ (1995 \& Supp. 1998) (home address, photo, date of birth, personal vehicle information, and occupation and name of employer); MiCH. COMP. LAWS ANN. § 28-727 (West Supp. 1999) (home address, date of birth, and description information); S.C. CODE ANN. \& 23-3-490 (Law Co-op. 1999) (home address, photo, identifying characteristics, and date of birth); TENN. CODE ANN. $\$ 40-39-103$ (1997) (home address, photo, and date of birth). Offense history information, often quite detailed in nature, is also disseminated as a matter of course.

${ }^{176}$ Paul P. v. Verniero, 170 F.3d 396, 404 (3d Cir. 1999). 
tion "that a significant number of persons . . . choose to list their telephones privately, because they regard their home addresses to be private information."177

Moreover, and of special significance here, the dissemination of address information raises concern for potential physical harm or harassment, a potential discussed at length in the Supreme Court's 1994 opinion in United States Department of Defense $v$. Federal Labor Relations Authority. There, Justice Thomas fretted over the prospect of federal employees receiving unsolicited mailings or phone calls from aggressive union organizers. ${ }^{178}$ If disclosure of one's address implicates a privacy right under such circumstances that in the Court's words is "nontrivial" and "far from insignificant," ${ }^{\prime 79}$ there most surely must be some protectible privacy interest relative to the disclosure of the addresses of sex offenders. ${ }^{180}$ Indeed, the substantial record of incidences of vigilantism and harassment of registrants would appear to amply validate this position. ${ }^{181}$ Merely because such harm stems from the behavior of "third parties" (i.e., fellow citizens) in no way

in Id.

${ }^{178}$ See supra notes 65-70 and accompanying text.

${ }^{179}$ See United States Dep't of Defense v. Federal Labor Relations Auth., 510 U.S. 490, 501 (1994). See also Kallstrom v. City of Columbus, 136 F.3d 1055, 1063 (6th Cir. 1998) (finding a fundamental privacy right implicated by governmental disclosure of personal information contained in personnel files of police officers, based on possible threats to "personal security").

A decision in the Eastern District of Michigan addressed a novel twist on this issue. See Akella v. Michigan Dept. of State Police, 67 F. Supp. 2d 716 (E.D. Mich. 1999). In Akella, homeowners claimed that their due process rights were violated when the address for their home erroneously remained on the Michigan registry for three years as a result of a prior resident's registrant status, and Michigan law provided no mechanism to correct the error. The plaintiffs alleged the " $[t]$ he stigma attached to living in a residence wrongly attributed to a sex offender may put many people in danger that they are not aware of." Id. at 731. Citing Kallstrom, the court rejected the claim because plaintiffs failed to allege that the incorrect listing subjected them to a "substantial risk of serious bodily harm." Id. at 732 (citing Kallstrom, 136 F.3d at 1064).

${ }^{180}$ Sez Doe v. Poritz, 662 A.2d 367, 409 (N.J. 1995) ("[W] disclosed under the Notification Law, plaintiff may be exposed to uninvited harassment, we conclude that disclosure of plaintiff's home address, particularly when coupled with the other information disclosed, implicates a privacy interest."). Cf. Ingraham v. Wright, 430 U.S. 651, 673 (1977) ("Among the historic liberties ... protected [by the Constitution] is a right to be free from ... unjustified [State] intrusions on personal security.").

${ }^{1 * l}$ See supra note 45. See also Kabat, supra note 46, at $339-40$ n.34 (listing numerous instances of vigilantism); Tracy L. Silva, Comment, Dial "1-900-PERVERT" and Other Statutory Measures That Provide Public Notification of Sex Offenders, 48 SMU L. REV. 1961, 1983-85 (1995) (listing other vigilante acts). 
should alter this conclusion, as some courts have held. ${ }^{182}$ Even assuming that government has no general duty to protect individuals from harm by third parties, ${ }^{183}$ the constitutional tableau is less clear when the government creates the danger, ${ }^{184}$ such as occurs when the government informs an entire anxious community that a sex offender is in its midst. ${ }^{185}$

Finally, it is important to recognize that notification entails disclosure of non-public information, further warranting protection. The publicly available information is merely the baseline information the State uses, supplemented by information often obtained from the registrant, that is used to make the inherently stigmatizing "sex offender" designation. As the Massachusetts Supreme Judicial Court has observed:

Constitutional privacy interests are implicated in these cases because the information to be disseminated would be obtained from the offenders themselves and by reason of their required acts of registration. The damage to their reputations resulting from such dissemination stigmatizes them as currently dangerous sex offenders, can harm their earning capacities, and can cause them to be objects of derision in the community.

In short, notwithstanding that public conviction serves to lessen offenders' expectations of privacy, it does not eliminate them. ${ }^{187}$ As the Supreme Court itself has emphasized, in determining "whether due process requirements apply in the first

In See, e.g., Russell v. Gregoire, 124 F.3d 1079, 1093 n.10 (9th Cir. 1997); Doe v. Kelley, 961 F. Supp. 1105, 1112 (W.D. Mich. 1997). See also Doe v. Pataki, 20 F.3d 1263, 1279-80 (2d Cir. 1997) (acknowledging that notification is "doubtless the 'but for' cause of some" acts of vigilantism, but rejecting that such acts are "fairly attributable to community notification" per se).

iss See DeShaney v. Winnebago Cty. Dep't of Social Servs., 489 U.S. 189, 197 (1989).

is Id.

18s See James W. Whitman, What is Wrong With Inflicting Shame Sanctions?, 107 YALE L.J. 1055, 1088 (1998) ("Once the state stirs up public opprobrium against an offender, it cannot really control the way the public treats the offender.... When our government dangles a sex offender or a drunk before the public, it has vanishingly little control over how the public treats the person."). Nor is it significant that many notification laws expressly prescribe criminal penalties for those making undue use of notification information to harass or commit acts of vigilantism against registrants. See Caroline Louise Lewis, The Jacob Wetterling Crimes Against Children and Sexually Violent Offender Registration Act: An Unconstitutional Deprivation of the Right to Privacy and Substantive Due Process, 31 HARV. C.R.-C.L. L. REv. 89, 106-12 (1996) (arguing same).

${ }^{186}$ Doe v. Sex Offender Registry Bd., 697 N.E.2d 512, 518 n.12 (Mass. 1998).

${ }^{187}$ See Doe v. Poritz, 662 A.2d 367, 411 (N.J. 1995) ("The interests in privacy may fade when the [offense history] information is a matter of public record, but they are not non-existent."). Cf. Liberty Lobby, Inc. v. Anderson, 746 F.2d 1568, 1568 (C.A.D.C. 1984) (Scalia, J.) ("Even the public outcast's remaining good reputation, limited in scope though it may be, is not inconsequential."). 
place, [the court] must look not to the 'weight' but to the nature of the interest at stake." 188 The perceived "severity" or "weight" of the deprivation, on the other hand, is a factor to be weighed in the evaluation of the form and extent of procedural protections to be afforded, pursuant to the three-part balancing test set forth in Matthews v. Eldridge. ${ }^{189}$

\section{The Paul "Stigma-Plus" Test}

There is also sound reason to conclude that more general application of the Supreme Court's "stigma-plus" test warrants due process safeguards. Having one's criminal sexual offense history made public and being labeled a "repetitive sex offender," or the like, plainly calls into question one's "good name, reputation, honor, or integrity." 190 Indeed, being labeled an "active shoplifter," as in Paul, or an alleged alcoholic, as in Constantineau, pales in comparison, given society's acute disdain for sex offenders, ${ }^{191}$ as manifest in the repeated acts of vigilantism experienced by registrants subject to community notification. ${ }^{192}$

${ }^{188}$ Board of Regents v. Roth, 408 U.S. 564, 570-71 (1972). See also Goss v. Lopez, 419 U.S. 565, 576 (1975); Morrissey v. Brewer, 408 U.S. 471, 481 (1972); Boddie v. Connecticut, 401 U.S. 371, 378-79 (1971); Sniadach v. Family Finance Corp., 395 U.S. 337, 342 (1969) (Harlan, J., concurring).

${ }^{189} 424$ U.S. 319, 334-35 (1976) ("[T] severity of the deprivation."). The upshot of the Matthews test, Massachusetts' highest court recently stated, is that "[d]eprivation of greater individual liberty interests requires greater procedures and stronger countervailing State interests." Doe v. Attorney Gen., 686 N.E.2d 1007, 1010 (Mass. 1997).

${ }^{190}$ Roth, 408 U.S. at 573 (quoting Wisconsin v. Constantineau, 400 U.S. 433, 437 (1971)).

${ }^{191}$ See supra notes 2-3 and accompanying text. As the Middle District of Alabama recently stated:

While it might seem that a convicted felon could have little left of his good name, community notification ... will inflict a greater stigma than would result from conviction alone. Notification will clearly brand the plaintiff as a "criminal sex offender" within the meaning of the Community Notification Act-a "badge of infamy" that he will have to wear for at least 25 years-and strongly implies that he is a likely recidivist and a danger to his community.

Doe v. Pryor, 61 F. Supp. 2d 1224, 1231 (M.D. Ala. 1999). See also Neal v. Shimoda, 131 F.3d 818,829 (9th Cir. 1997) (recognizing the "stigmatizing consequences of being labeled a sex offender"); Doe v. Attorney Gen., 686 N.E.2d 1007, 1016 (Mass. 1997) (Fried, J., concurring) (referring to "continuing, intrusive, and humiliating regulation of the person himself" associated with registration and notification).

${ }^{192}$ See supra note 45 and accompanying text. 
This stigma is increased immeasurably as a result of the communicative methods used in notification systems which, unlike the limited posting of flyers within local stores at issue in Paul and Constintineau, involve use of the media, the Internet, flyers and postings, and even door-to-door visits by law enforcement (or the registrant himself) to disseminate registrant information. ${ }^{193}$ In actuality, as the Supreme Court of Oregon recently observed, conceiving of the issue in terms of "reputation" understates what is at issue. When the government gathers and synthesizes harmful information in order to label one of its citizens in a derogatory manner "the interest of the person to be labeled goes beyond mere reputation .... It is an interest in knowing when the government is moving against you and why it has singled you out for special attention. It is an interest in avoiding the secret machinations of a Star Chamber."194

The "plus" requirement of Paul would appear satisfied as well. As discussed, the laws adversely affect personal privacy because of the release of home and work address information. ${ }^{195}$ The laws also modify the basic legal status of freed sex offenders who, although they have served their sentences, must maintain their registration for perhaps the rest of their lives, ${ }^{196}$ under threat of prosecution if they do not. ${ }^{197}$ Moreover, registrants typically suffer statutorily imposed limits on the places they are permitted to live ${ }^{198}$ and their capacity to change names, ${ }^{199}$ and

193 See supra note 35.

${ }^{194}$ Noble v. Board of Parole \& Post-Prison Supervision, 964 P.2d 990, 995 (Or. 1998).

${ }^{195}$ See supra notes $175-77$ and accompanying text.

${ }^{106}$ See supra note 46 and accompanying text.

${ }^{197}$ See, e.g., ALASKa STAT. § 11-56.835 (Michie 1999) (class " $\mathrm{C}^{\text {n }}$ felony); ARIz. REv. STAT. ANN. $\S 13-3824$ (West 1999) (class "4" felony); MICH. CoMp. LAWS ANN. § 28-729 (West Supp. 1999) (felony); WASH. REv. CODE. ANN. § 9A.44.130(9) (West Supp. 1999) (class "C" felony).

${ }^{190}$ See, e.g., ALA. CODE § 15-20-26 (1999); MiNN. STAT. § 244.052(sub. 3) (k), (sub.4) (1999). See also Toum Restricts Sex Offenders, DENVER ROCKY MTN. NEWS, Aug. 26, 1999, at 39A, available in LEXIS, News Group File (relating that local town board of Denver suburb enacted an ordinance prohibiting more than one registered sex offender from living together). Plainly, such limits implicate protectible "associational rights" of offenders. See generally TRIBE, supra note 55, § 1517. Although such living constraints are commonly imposed as probation or parole conditions, the duration of registration and notification typically extends far beyond customary probation or parole periods.

${ }^{199}$ See, e.g., CAL. CIv. PROC. CODE $\$ 1279.5$ (West Supp. 1999) (no change unless "it is in the best interest of justice to grant [the change] and that doing so will not adversely affect the public safety. ${ }^{n}$ ); 730 ILL. COMP. STAT. 5/21-101 (West 1999) (no change for duration of required registration); N.H. REV. STAT. ANN. § 547:3-i(II) (1997 \& Supp. 1999) (allowed only if registrant "makes a compelling showing that a name change is necessary"). 
are even required to pay fees to help cover the operational costs of the registration and notification systems. ${ }^{200}$

Of all the obvious "pluses," however, two stand out with respect to the Supreme Court's settled jurisprudence. First, offenders suffer palpable limits on their "occupational liberty." As Chief Judge Richard Posner has noted, "[t]he distinction between mere defamation and an infringement of liberty of occupation is merely one of degree, especially when the defamation relates to a person's fitness for a particular type of employment, but it is a distinction to which the courts are committed." ${ }^{202}$ Registration and notification laws satisfy this standard, because they discourage employers from hiring or retaining eligible offenders, and at times expressly bar offenders from certain employment. ${ }^{203}$ These limits, in turn, are backed up by the threat of civil fines for employers should a registrant not be terminated. ${ }^{204}$

A second obvious "plus" comes in the form of the widespread grants of statutory immunity to government officials involved in the registration and notification process, grants which effectively preclude eligible offenders from seeking redress in the courts. As noted earlier, the Minnesota Court of Appeals identified the legislative grant of immunity as a "plus" because it rendered nugatory the "Remedies Clause" of the Minnesota Constitution. ${ }^{205}$ Numerous other state constitutions expressly provide a similar right of access or remedy. ${ }^{206}$ Even in the ab-

\footnotetext{
${ }^{20}$ See, e.g., IDAHO CODE § 18-8307(4) (Supp. 1999); 730 ILL. COMP. STAT. ANN. 150/3(c) (6) (West Supp. 1999).

${ }^{201}$ Paul v. Davis, 424 U.S. 693, 710 (1976) (holding that stigma must "foreclose" one's freedom to take advantage of employment opportunities). See also Connecticut v. Gabbert, $119 \mathrm{~S}$. Ct. 1292, 1225-26 (1999) ("[T]he liberty component of the Fourteenth Amendment's Due Process Clause includes some generalized due process right to choose one's field of private occupation .... . ); Schware v. Board of Bar Examiners, 353 U.S. 232, 238-39 (1957) (holding that a state cannot, without affording due process, foreclose a range of employment opportunities).

${ }_{202}$ Olivieri v. Rodriguez, 122 F.3d 406, 408 (7th Cir. 1997).

${ }^{203}$ See, e.g., ALA. CODE $§ 15-20-26$ (a) (1999) (school or child care facilities); MINN. STAT. § 244.052(sub.3) (k), (sub.4) (same) (1999).

${ }^{204}$ See, e.g., IND. CODE ANN. § 5-2-12-12 (West Supp. 1999); OKLA. STAT. ANN. tit. 57, § 584(F) (West 1999).

${ }^{200}$ See supra note 163 and accompanying text.

${ }^{200}$ See, e.g., KAN. CONST., Bill of Rights, $\S 18$ ("All persons, for injuries suffered in person, reputation or property shall have remedy by due course of law ...."); OR. CONST., art. I, $\$ 10$ ${ }^{(}[\mathrm{E}] \mathrm{E}$ ery man shall have remedy ... for injury done him in his person, property, or reputation."). See generally Jonathan M. Hoffman, By the Course of the Law: The Origins of the Open Courts
} 
sence of a constitutional guarantee, however, a fair reading of Paul compels that statutory immunity, which effectively bars the right of access to the courts, satisfies the "plus" test. In holding that damage to "mere reputation" was not actionable for constitutional purposes, the Paul majority attached obvious importance to the fact that state law otherwise provided a plaintiff an avenue of redress and access to judicial process. ${ }^{207}$ Immunity, however, precludes such redress, raising clear constitutional concern. ${ }^{20}$

Further support for fulfillment of the Paul test is found in the strikingly similar context of "child abuse registries," with courts evincing an obvious sensitivity for the liberty interest implicated by that form of governmental stigmatization. For instance, the Eighth Circuit has identified a protectible interest in reputation jeopardized by the stigma associated with being placed on such a registry, accompanied by "pluses" of losses in privacy and the stability and autonomy of family relationships. ${ }^{209}$

Clause of State Constitutions, 74 OR. L. REv. 1279 (1995); David Schuman, The Right to a Remedy, 65 TEMP. L. REV. 1197 (1992).

${ }^{207}$ Paul v. Davis, 424 U.S. 693, 712 (1976) ("[Plaintiff's] interest in reputation is simply one of a number which the State may protect against injury by virtue of its tort law, providing a forum for vindication of those interests by means of damages actions."). Professors Rotunda and Nowak have observed with respect to Paut

The ruling that mere injury to reputation does not constitute a deprivation of liberty thus may mean only that the injured person must be satisfied with a tort remedy which follows the defamatory action. If the State had no tort action for libel against such officialsif the state granted its public officials immunity to defame private citizens while otherwise recognizing [a] defamation action-it would raise a much more serious question as to whether the State was depriving someone of liberty or property by allowing the government to damage his name with no hope of rectifying the harm done.

ROTUNDA \& NoWAK, supra note $99, \S 17.4$, at 66 (emphasis added). They add that Justice Stevens "has indicated that he believes this "later process' is a better rationale for the opinion." Id. (citing Ingraham v. Wright, 430 U.S. 651, 700-02 (1977) (Stevens, J., dissenting)).

${ }^{200}$ See Paul, 424 U.S. at 710-11 ("[Liberty interests arise] by virtue of the fact that they have been initially recognized and protected by state law, and we have repeatedly ruled that the procedural guarantees of the Fourteenth Amendment apply whenever the State seeks to remove or significantly alter that protected status.") (footnote omitted).

${ }^{200} \mathrm{See}$ Bohn v. County of Dakota, 772 F.2d 1433, 1436 n.4 (8th Cir. 1985). Cf. Watson v. Colorado Dep't of Soc. Servs., 841 P.2d 299, 307.09 (Colo. 1992) (recognizing a liberty interest based on family stability and autonomy as a result of being placed on child abuse registry, but finding no due process violation because the information was kept confidential). But see Paul P. v. Verniero, 170 F.3d 396, 405 (3d Cir. 1999) (finding family-related effects of notification too "indirect" to implicate privacy interest under federal law).

The Supreme Court of New Hampshire, construing the State Constitution, found a liberty interest to be at stake in conjunction with placement of the names of two parents on a child neglect registry, which was not disseminated to the public at-large. See In re Lana \& Leon Bagley, 513 A.2d 331 (N.H. 1986). Recognizing the stigma that attended the governmental determina- 
Similarly, in Valmonte $v$. Bane $e^{210}$ the Second Circuit found Paul satisfied with respect to the New York child abuse registry. ${ }^{211}$ Significantly, while the information was not disseminated to the public at large, employers in the child care field were required to consult the registry to determine whether potential employees were listed. The Valmonte court found that inclusion on the registry was sufficiently stigmatizing under $P a u l_{,}^{212}$ and that the statutorily mandated revelation to prospective employers in the child-care field alone amounted to a "specific deprivation of [plaintiff's] opportunity to seek employment." ${ }^{213}$ The New York Court of Appeals reached the identical result with respect to the New York child abuse registry, ${ }^{214}$ as have courts in New Jersey, ${ }^{215}$ Georgia, ${ }^{216}$ and Nebraska ${ }^{217}$ with respect to their registries.

tion, the court reasoned that at the moment of their placement on the registry the plaintiffs' "lives became a little more complicated and a little less free." Id. at 338. See also Minnehan v. Department of Soc. Servs., No. 98-4687, 1999 WL 706653, at*12 n.17 (Mass. Super. Ct. Aug. 14, 1999) ("[R]eliance on Paul v. Davis for the proposition that governmental injury to reputation implicates no liberty interest unless that injury also alters some other right or status cannot possibly be read to suggest that such injury is inconsequential. Manifestly, it is not.").

${ }_{210} 18$ F.3d 992 (2d Cir. 1994).

211 $I d$. at 999 .

${ }^{212} I d$. at $999-1000$.

${ }^{213}$ Id. at 1001 . Although the record reflected that the plaintiff had worked only as a "paraprofessional in the school system," the Valmonte court accepted as true that "she would look for a position in the child care field but for her presence on the Central Register." Id. at 999. The actual impediment to the plaintiff's job prospects was two-fold "by operation of law": (1) potential employers would be informed specifically about her status, making them less likely to hire her; and (2) even if they wished to hire her, the New York law required that they provide written reason why they deemed her "appropriate" for employment in the child care field, a further impediment. Id. at 1001.

Similarly, the Fourth Circuit "assume[d]" that the government's listing of the plaintiff on the Virginia registry implicated the plaintiff's liberty interest, because "this listing indirectly cost him his job." Perry v. City of Norfolk, No. 98-2284, 1999 WL 731100, *5 (4th Cir. Sept. 20, 1999).

${ }_{214}$ See Lee T.T. v. Dowling, 664 N.E.2d 1243, 1250 (N.Y. 1996). The New York Court of Appeals, with similar analysis, has also found Paul satisfied with respect to those suspected of abuse and listed on the State Nurse Aid Registry, which involves dissemination to the public at-large. See In re Miller v. DeBuono, 689 N.E.2d 518, 522 (N.Y. 1997). The Miller court stated: "by publicly branding petitioner a patient abuser, the State's action affects not only her occasion for employment in the residential health care industry, but also may well extend to prevent future employment opportunities in any arena, thereby placing a tangible burden on her employment prospects." Id.

${ }^{215}$ See New Jersey Div. of Youth \& Family Servs. v. M.R., 715 A.2d 308, 315 (N.J. Super. Ct. App. Div. 1998); In re Allegations of Sexual Abuse at East Park High School, 714 A.2d 339, 34647 (N.J. Super. Ct. App. Div. 1998).

${ }^{216}$ See State v. Jackson, 496 S.E.2d 912, 915 (Ga. 1998). The court distinguished Paul, reasoning that "more than Jackson's reputation is involved. The State is attempting to take further official action against him, based on the same alleged acts that underlie his criminal prosecution." Id. 
In short, if in Constantineau the limits placed on the plaintiff's right "to purchase or obtain liquor" sufficed as a "plus,",18 the litany of harms and deprivations associated with sex offender notification manifestly do also.

\section{Fundamental Faimess}

Beyond the core constitutional rationale just discussed, basic fairness dictates that notice and an opportunity to be heard precede community notification.

As a threshold matter, although notification is justified "to protect the public from registered offenders,",19 it is clear that the broad scope of predicate offenses triggering registration and notification, including mere attempts to commit specified crimes ${ }^{220}$ can overshoot this mark. For example, in State v. Patterson, ${ }^{221}$ the petitioner pled guilty to burglary and misdemeanor theft in relation to his taking of several items of female underwear from his neighbor's apartment. The trial court concluded that he therefore was required to register under the Kansas Sex Offender Registration Act, which permits public access to the registry. ${ }^{222}$ The central question before the Kansas Court of Appeals was whether the acts were "sexually motivated," statutorily defined as meaning "that one of the purposes for which the defendant committed the crime was for the purpose of the defendant's sexual gratification."223 The Patterson court held in the affirmative, inferring that the Kansas Legislature "was concerned with those offenders who commit crimes not commonly

${ }^{217}$ See Shearer v. Leuenberger, 591 N.W.2d 762, 777 (Neb. 1999). According to the court, "[t]he placement of Shearer's name on the Registry . . . was required by state law. It had the imprimatur of official action, which usually implies that the information at issue has been tried and tested according to the dictates of due process . ..." Id.

${ }^{218}$ See Paul v. Davis, 424 U.S. 693, $708-09$ (1996) (summarizing result in Wisconsin v. Constantineau, 400 U.S. 433, 437 (1971)). See also In re C.M., 578 N.W.2d 391, 398 n.5 (Minn. Ct. App. 1998) ("[T] he great weight of the stigma [associated with being labeled a Level III sex offender] compensates for the relative uncertainty in establishing the other element.").

${ }^{219}$ See Final Guidelines, supra note 30, at 581. See also 42 U.S.C. \$ 14071 (e) (2) (1995 \& Supp. 1999) (specifying that jurisdictions "shall release relevant information that is necessary to protect the public ...").

${ }^{200}$ See, e.g., 42 U.S.C. $\$ 14071$ (a) (3)(A) (viii)(I) (1995); NEV. REv. STAT. ANN. \$ 207.151(3) (Michie 1997); N.D. CENT. CODE § 12.1-32-15 (1999); OKLA. STAT. ANN. tit. 57, § 582 (West 1996); S.C. CODE ANN. § 23-3-430(c) (Law Co-op. 1999).

${ }^{221} 963$ P.2d 436 (Kan. Ct. App. 1998).

272 See id. at 437.

${ }^{22 s}$ Id. at 438 (citing KAN. STAT. ANN. § 22-4902(b)(12)). 
called sex crimes, but which nevertheless are criminal offenses committed by persons seeking sexual gratification."224

Likewise, Washington State requires registration of those committing any crime "for the purpose of sexual gratification," ${ }^{225}$ Indiana for "vicarious sexual gratification," 226 and Colorado for conviction of "unlawful sexual behavior."227 In California, statutory law permits courts to require registration "for any offense not included specifically in this section if the court finds at the time of conviction that the person committed the offense as a result of sexual compulsion or for the purposes of sexual gratification."228 Furthermore, seizing upon manifest broad legislative intent, courts have permitted registration and notification when individuals have only been charged with, but not convicted of, an enumerated sexual offense. ${ }^{229}$ Finally, in one of the most expansive holdings to date, the Connecticut Supreme Court concluded that probation officers can carry out notification with respect to a probationer, notwithstanding that he pled guilty to a non-enumerated offense. ${ }^{230}$ As a result, the local school principal, and probationer's neighbors and "fellow

${ }^{224}$ Id. at 439. The court noted that it had "some concern over the possibility that this statute could be extended beyond reason. For instance, would a defendant fall under the provisions of the KSORA if he or she stole contraceptives or engaged in disorderly conduct by shouting sexually explicit words?" Id. at 440. See also State v. Myers, 923 P.2d 1024, 1042 (Kan. 1996) (expressing concern that the sweep of the registration requirement "could apparently include any 'sexually motivated' act resulting in an 'offense," including non-felonies).

${ }^{223}$ See WASH. REv. CODE ANN. §§ 9A.44.130, 9.94A.127 (West 1997). See also State v. Halstien, 857 P.2d 270, 282 (Wash. 1993) (requiring registration of paperboy who broke into a woman's home and stole a box of condoms and a vibrator).

${ }^{226}$ See IND. CODE $\$ 5-2-12-4$ (1) (E) (West Supp. 1999).

${ }^{27}$ See Colo. Rev. STAT. ANN. § 18-3-412.5 (West 1997). See also, e.g., ALA. CODE § 13A-11-200 (1997) ("act of sexual perversion"); CAL. PENAL CODE $\$ \S 272,290$ (West 1997) ("lewd and lascivious behavior"); WYO. STAT. ANN. § 7-19-301(a)(v) (Michie 1998) ("taking indecent liberties").

${ }^{22 s}$ CAL. PENAL CODE $\$ 290$ (a) (2) (E) (West 1997).

${ }^{225}$ See, e.g., People v. Meidinger, 987 P.2d 937, 938-39 (Colo. Ct. App. 1999) (affirming required registration of offender who pled guilty to contributing to the delinquency of a minor, a non-enumerated offense, because of the "underlying circumstances of the offense"). But see Whitehead v. State, 985 P.2d 1019, 1020 (Alaska Ct. App. 1999) (denying right to sentencing judges to require registration of offenders convicted of non-enumerated offenses); In re C.M., 578 N.W.2d 391, 399 (Minn. Ct. App. 1998) (finding due process violation when notification permitted when offender charged with, but not convicted of, a sex offense).

${ }^{200}$ See State v. Misiorski, 738 A.2d 595, 602 (Conn. 1999). 
bowling league participants" were provided with sensitive registration information. ${ }^{2 / 1}$

Even in the absence of such expansive statutory language or judicial behavior, jurisdictions have prescribed a broad gamut of non-violent offenses as sufficient to trigger registration and notification, ${ }^{232}$ targeted juveniles, ${ }^{233}$ and at times otherwise failed to impose a time limit for registration-eligible offenses. ${ }^{234}$ Exacerbating this breadth, states rarely provide registrants a right to appeal the eligibility determination, ${ }^{235}$ and the sole federal appellate court directly addressing the issue (the Ninth Circuit) has held that state registrants cannot avail themselves of federal habeas relief because they are not "in custody" as required by 28 U.S.C. $§ 2254(\mathrm{a}) .^{236}$ Nor must suspects always be apprised at the

${ }^{231}$ Id. at 598-600. Compare id. at 604 (Berdon, J., dissenting) ("[T] he majority's grant of fascistic powers to probation officers cuts away a pound of flesh from the constitutional right to privacy.").

${ }_{232}$ See, e.g., ALA. CODE §§ 13A-11-200, 13A-12-131 (1997) (posting obscene bumper sticker); ARIZ. REV. STAT, ANN. $\$ \$ 13-3821,13-1402,13-1408$ (West 1997) (indecent exposure and adultery); CAL. PENAL CODE $§ \S 290,647$ (d) (West Supp. 1997) (loitering outside a public restroom for lewd or lascivious purposes); LA. REv. STAT. ANN. §§ 14:76, 15:542(E) (West 1997) (bigamy); N.M. STAT. ANN. §§ 29-11A-3, 30-6A-3 (Michie 1997) (possession of sexually explicit photo of minor); OHO REv. CODE ANN. $\$ \S 2907.08,2907.09,2950.01$ (D) (1) (Anderson 1996) (public indecency, voyeurism); S.C. CODE ANN. \$23-3-430(C)(12) (1999) ("peeping").

In a case garnering national attention, an 18-year-old Wisconsin boy was prosecuted for having consensual relations with his 15-year-old girlfriend, making him subject to registration as a sex offender. See Roberto Suro, Town Faults Law, WASH. POST, May 11, 1997, at A1. In a similar case, in Kansas, a 20-year old male was forced to register as a result of having sex with a 15-yearold female, who he mistakenly thought was of legal age because she was drinking beer in a tavern. See Tony Rizzo, Relatives Fall Victim to Sex Laws; Offenders' Families Have Been Harassed By Taunts and Hate Mail KANSAS CrTY STAR, Nov. 1, 1994, at A1 (noting that most offenders subject to registration "are lower-level offenders who received probation rather than prison after they were convicted"). See also Doe v. Attorney Gen., 686 N.E.2d 1007 (Mass. 1997) (holding that due process must be accorded male who was forced to register upon being convicted for propositioning an undercover officer in a highway rest area reputedly popular for consensual sex between adult males); Kevin Simpson, Sex-Case Penalty Questioned; Teenager Suffers as Listed Offender; DENVER POST, Aug. 8, 1999, at B1 (discussing 15-year-old boy forced to register as result of fondling female classmate).

${ }_{23 s}$ See, e.g., In re Matter of Welfare of C.D.N., 559 N.W.2d 431, 435 (Minn. 1997); State v. Haskell, 916 P.2d 366, 372 (Wash. 1996). See generally Earl F. Martin \& Marsha K. Pruett, The Juvenile Sex Offender and the Juvenile Justice System, 35 AM. CRIM. L. REv. 279, 313-32 (1998); Mark J. Swearingen, Comment, Megan's Law as Applied to Juveniles: Protecting Children at the Expense of Chitdren?, 7 SETON HALL CONST. L.J. 525 (1997).

${ }^{24}$ See, e.g.,William Claiborne, At the Los Angeles County Fair, "Outing" Sex Offenders, WaSH. POST, Sept. 20, 1997, at A1 (noting that California's sex offender registry includes individuals convicted decades ago of consensual homosexual acts that are no longer prosecuted).

${ }^{23}$ See, e.g., People v. Adams, 144 Ill. 2d 381, 387 (Ill. 1991) (no statutory right of appeal).

${ }^{2 s s}$ See McNab v. Kok, 170 F.3d 1246, 1247 (9th Cir. 1999) (construing Oregon law); Williamson v. Gregoire, 151 F.3d 1180, 1184 (9th Cir. 1998) (construing Washington law). Elsewhere the Ninth Circuit has expressed constitutional concern over the simultaneous denial of a right 
time they enter a guilty plea that they will be subject to registration and notification," on the reasoning that they are "collateral" and not "direct" effects of the plea.

Finally, contrary to the teleological reasoning of the Eastern District of Michigan and Illinois Court of Appeals in opinions discussed above, ${ }^{238}$ the fact that a particular jurisdiction's registration and notification scheme does not differentiate among offenders, and thus relies exclusively upon blanket legislative assessment of community danger, should not alter the liberty interest analysis. The constitutional question is not whether offender differentiation is contemplated by the particular statutory scheme in question; rather, it is whether a liberty interest

to appeal and recourse to habeas corpus. See Magana-Pizano v. I.N.S. 152 F.3d 1213, 1221-22 (9th Cir. 1998), rev'd on other grounds, 119 S. Ct. 1137 (1999).

${ }^{237}$ See Roe v. Farwell, 999 F. Supp. 174, 183 (D. Mass. 1998); Robinson v. State, 730 So. 2d 252, 254 (Ala. Crim. App. 1998); People v. McClellan, 862 P.2d 739 (Cal. 1993); State v. Skroch, 883 P.2d 1256 (Mont. 1994); State v. Timperley, 599 N.W.2d 866, 869 (S.D. 1999); Guzman v. State, 993 S.W.2d 232, 236 (Tx. Ct. App. 1999); State v. Ward, 869 P.2d 1062, 1076 (Wash. 1994).

A few courts have found that such a failure to advise undercuts the requisite voluntariness of the plea. See United States v. Coenen, 135 F.3d 938, 943 (5th Cir. 1998) (finding that defendant was entitled to pre-sentence notice that the court was considering as a condition of supervised release community notification, likening notification to "upward departure" under U.S. Sentencing Guidelines); State v. Calhoun, 694 So. 2d 909, 914 (La. 1997) (voluntariness of plea undercut by failure to advise defendant of registration and notification requirements). $C f$. Peterson v. State, 988 P.2d 109, 119-20 (Alaska Ct. App. 1999) (invalidating unadvised plea because legislature expressly revised guilty plea procedure to guard against same). In In re Birch, the California Supreme Court set aside a plea for "lewd and lascivious" behavior, based on urinating in public, because the defendant was not advised that he would be required to register as a sex offender. 515 P.2d 12, 12-13, 17 (Cal. 1973). The Birch court noted that "[a]lthough the stigma of a short jail sentence should eventually fade, the ignominious badge carried by the convicted sex offender can remain for a lifetime," and "[w] henever any sex crime occurs in his area, the registrant may very well be subjected to investigation." Id. at 17.

${ }^{2 s 3}$ See supra notes 125-33 and accompanying text.

Very recently, the Alaska Court of Appeals used this same reasoning in its rejection of a due process claim. See Patterson v. State, 985 P.2d 1007 (Alaska Ct. App. 1999). Under Alaska law, all statutorily eligible offenders are required to provide local police with registration information, including name, home address, place of employment, and a photo, which is made available on the Internet and upon request. The lack of due process afforded to prospective registrants was of no constitutional moment because:

[petitioner] show[ed] no authority that limits the legislature from providing full access in all cases. Under [the Act], a sex offender's risk of re-offense is a matter of judgment for any member of the public who uses the Department's registry. The legislature decided that the fact of an offender's conviction for a sex offense was sufficient reason to include that offender in the registry because of the potential for re-offense. It is not an irrational conclusion for the legislature to create the sex offender registry in response to the potential for recidivism that sex offenders have as a group. Because [the Act] ... does not require any administrative adjudication, we conclude that [petitioner] has not been deprived of procedural due process.

Id. at 1017. 
exists sufficient to warrant due process protection. This precise question was addressed by Massachusetts' highest court in 1997. In Doe v. Attomey General, ${ }^{239}$ the petitioner was convicted of indecent assault and battery, and deemed a "Level 1" offender. As such, Massachusetts statutory law did not afford him an opportunity to challenge the requirement that he register, and be subject to notification on request, for a period of at least 15 years following conviction. ${ }^{240}$ The Massachusetts court squarely held that this violated due process:

It is contrary to the principle of fundamental fairness that underlies the concept of due process of law to deny the plaintiff a hearing at which the evidence might show that he is not a threat to children and other vulnerable persons whom the act seeks to protect and that disclosure is not needed when balanced against the public need to which the sex offender act responded. Government action stigmatizing the plaintiff would violate the plaintiff's constitutionally protected rights. The plaintiff is entitled to a hearing and a determination as to whether he must register under the act and, if so, whether sex offender information concerning him should be available on request. ${ }^{241}$

In short, fundamental fairness dictates that due process rights be accorded those threatened with notification. The Supreme Court itself has stated that procedural due process serves two central concerns: "the prevention of unjustified or mistaken deprivations and the promotion of participation and dialogue by affected individuals in the decision-making process."242 Given the uncertainties associated with the accurate assessment of risk posed by offenders, ${ }^{243}$ and the blunderbuss range of offenses triggering registration and notification, ${ }^{244}$ fairness requires that

${ }^{200} 686$ N.E.2d 1007 (Mass. 1997).

${ }^{200}$ Id. at 1014. In Opinion of the Justices to the Senate, 668 N.E.2d 738, 753-55 (Mass. 1996), the court held that Level 3 and 2 offenders were entitled to due process, but did not address the due process rights of Level 1 offenders. See Doe, 686 N.E.2d at 1013 n.9 (noting same).

211 Id. at 1014. Under Massachusetts law, the following information was provided upon request: the offender's name, home address, work address, offense and date of adjudication, age, sex, race, height, weight, eye and hair color, and photograph, if available. See Fanvell, 999 F. Supp. at 196 n.14.

${ }_{242}$ Marshall v. Jerrico, 446 U.S. 288, 242 (1980). See also Greeholtz v. Inmates of the Nebraska Penal and Correctional Complex, 442 U.S. 1, 13 (1979) ("The function of legal process, as that concept is embodied in the Constitution, and in the realm of factinding, is to minimize the risk of erroneous decisions.").

${ }^{243}$ See supra note 43 (describing difficulties associated with assessing recidivism risks among sex offenders).

${ }^{2+1}$ See supra notes 219-34 and accompanying text (discussing broad statutory eligibility criteria for registration and notification). 
notice and a pre-notification hearing occur so that erroneous assessments, and their social and monetary costs, can be minimized. ${ }^{245}$ The second due process interest, the benefits of offender participation, ${ }^{246}$ would also appear amply served, and have further possible benefits in the form of increasing the likelihood that offenders will more fully comply with registration/notification requirements, if imposed, and even have therapeutic value. ${ }^{247}$ Finally, any provision of limited postnotification review of such inherently stigmatizing action, once undertaken, ${ }^{248}$ is not constitutionally sufficient, as repeatedly made clear by the Supreme Court. ${ }^{249}$

${ }^{25}$ Ironically, over-classification of offenders can conceivably also undercut the capacity, and willingness, of law enforcement to closely monitor the many offenders compelled to register. See In re Registrant E.I., 693 A.2d 505, 508 (N.J. Super. Ct. App. Div. 1997) ("[I]f Megan's Law is applied literally and mechanically to virtually all sexual offenders, the beneficial purpose of this law will be impeded."). Cf. New York Times Co. v. Sullivan, 403 U.S. 713, 729 (1971) (Stewart, J., concurring) ("[W] hen everything is classified, then nothing is classified, and the system becomes one to be disregarded by the cynical or the careless."). Indeed, jurisdictions are just now beginning to feel the economic and personnel strain entailed in broad registration and notification schemes. See, e.g., Kay Lazar, States Lack Money, Manpower to Do the Job, BOSTON HERALD, July 19, 1998, at 9, available in LEXIS, News Group File; Jonathan D. Rockoff, Notification Process of Sex Offenders Runs into Difficulties, PROVIDENCE JOURNAL, Mar. 28, 1999, at 2.

${ }^{246}$ See TRIBE, supra note $55, \S 10-7$, at 667 (emphasis in original):

$[T]$ he case for due process protection grows stronger as the identity of the persons affected by a governmental choice becomes clearer, and the case becomes stronger still as the precise nature of the effect on each individual comes more determinedly within the decisionmaker's purview. For when government acts in a way that singles out identifiable individuals ... it activates the special concern about being personally talked to about the decision rather than simply being dealt with.

${ }^{217}$ See Winick, supra note 14, at 565 (noting that "affording offenders an opportunity to participate through a hearing process can have significant therapeutic value" and might encourage a "willingness to accept [the] outcome and to comply with it"). Professor Winick adds that an evaluative hearing can lessen the self-denial common among sex offenders in that it "will place sex offenders in the position of advocating that they are amenable to treatment and rehabilitation and that their present risk of reoffending is reduced." Id. at 566. See generally TOM R. TYLER, WHY PEOPLE OBEY THE LAW (1990) (discussing the key role of perceived fairness and legitimacy in the likelihood that individuals will follow the law).

${ }^{2 * 3}$ See Kabat, supra note 46 , at 343 (noting that in 29 states registrants enjoy a right to petition for reconsideration of notification decisions, after notification has occurred, with success turning on rehabilitation or subsequent decrease in perceived dangerousness).

${ }_{249}$ See, e.g., Cleveland Bd. of Educ. v. Loudermill, 470 U.S. 543, 546 (1985) ("An essential principle of due process is that a deprivation of life, liberty or property "be preceded by notice and opportunity for hearing appropriate to the nature of the case."') (citations omitted).

Post-deprivation hearings, the Court has held, are not to occur except in "extraordinary situations where some valid governmental interest is at stake that justifies postponing the hearing until after the event." Fuentes v. Shevin, 407 U.S. 67, 82 (1972) (citing Boddie v. Connecticut, 401 U.S. 371,379 (1971)). A post-deprivation hearing is also appropriate when the government is "unable to anticipate and prevent a random deprivation of a liberty interest." Zinermon v. Burch, 494 U.S. 113, 132 (1990). Given that those subject to notification are either undergoing prosecutions or on the verge of prison release, neither such exceptional circum- 


\section{Things to Come: The Enduring Ambiguity of PAUL AND the SHRINKING SPECTRUM OF PROTECTIBLE "LIBERTY"}

To date, the Supreme Court has not directly addressed whether sex offenders possess a liberty interest sufficient to require that they be afforded procedural due process prior to being subject to notification. ${ }^{250}$ Given the large number of jurisdictions lacking procedural safeguards, however, ${ }^{251}$ due process challenges are certain to rise with increasing frequency. Importantly, the federal government, for its part, has adopted the position that "there is no liberty interest involved in community notification." ${ }^{252}$ This view has been endorsed by a significant number of courts, most notably the Sixth and Ninth Circuits, ${ }^{253}$ and is a position echoed by some commentators as well. $^{254}$

In light of the pendency of the issue, it is important to consider how the Supreme Court itself might resolve the question of whether sex offenders possess a liberty interest sufficient to compel due process.

stance would appear to be at play. In short, as the Massachusetts Supreme Judicial Court has stated with respect to the timing of the notification decision: "[o]nce the plaintiff is harmed, at best it will not easily be remediable." See Doe v. Attorney Gen., 680 N.E.2d 97, 100 (Mass. 1997).

${ }^{250}$ The Court has, however, denied certiorari in several cases raising other constitutional claims against registration and notification. See Russell v. Gregoire, 124 F.3d 1079 (9th Cir. 1997), cert. denied, 118 S. Ct. 1191 (1998); Doe v. Pataki, 120 F.3d 1263 (2d Cir. 1997), cert. denied, 118 S. Ct. 1066 (1998); E.B. v. Verniero, 119 F.3d 1077 (3d Cir. 1997), cert. denied sub. nom. W.P. v. Verniero, 118 S. Ct. 1039 (1998).

25! See supra notes $36-47$ and accompanying text.

${ }^{252}$ See DENA T. SACCO, Arguments Used to Challenge Notification Laws-and the Government's Response, in NATIONAL CONFERENCE ON SEX OFFENDER REGISTRIES, supra note 25, at 50, 51. At the time of publication, Ms. Sacco served as Counsel in the Office of Policy Development, U.S. Department of Justice. Ms. Sacco adds:

The laws provide information only. They do not impose any restraint on the offender .... Offenders contend that ... they will be shunned and avoided and denied jobs and places to live. That is not a State-imposed restraint on liberty because these things are not requirements of or the intent of notification laws. To the extent that such things even occur, they are the normal societal consequences of committing a heinous crime.

Id. at 51-52.

${ }^{23 s}$ See Cutshall v. Sundquist, 193 F.3d 466 (6th Cir. 1999); Russell v. Gregoire, 124 F.3d 1079 (9th Cir. 1997).

${ }^{25}$ See, e.g., Daniel L. Feldman, The "Scarlet Letter Laws" of the 1990s: A Response to the Critics, 60 ALB. L. REV. 1081, 1117 (1997) (arguing that the "stigma-plus" test is not satisfied and that no liberty interest otherwise exists); McAllister, supra note 163, at 19 ("[It is not] at all obvious precisely what liberty interest or fundamental right sex offenders have in concealing such information. Without a protected liberty interest or fundamental right at stake, the equal protection, substantive and procedural due process challenges are almost certainly doomed. ${ }^{n}$ ). 


\section{A. HOW THE COURT WILL APPLY PAUL IS UNCLEAR}

While the majority of lower courts that have used Paul to address the question of whether sex offender notification implicates a liberty interest have answered in the affirmative, ${ }^{255}$ and with good reason, ${ }^{256}$ it remains far from certain how the Supreme Court would resolve the issue. ${ }^{257}$ Indeed, although the Paul "stigma-plus" test is over twenty years old, it continues to perplex courts. As the Second Circuit has stated, "it is not entirely clear what the 'plus' is ... . Although Paul is the foundation for all subsequent cases dealing with governmental defamation, its meaning is not unambiguous."258

For instance, although numerous reviewing courts have deemed the "plus" requirement satisfied by registrants' loss or infringement of job opportunities, ${ }^{259}$ a close reading of the Paul facts reveals that, in fact, the plaintiff alleged impairment of future employment opportunities, which the Paul majority deemed non-actionable as a matter of law. ${ }^{260}$ Construing Paul in its 1994 decision in Valmonte v. Bane, ${ }^{261}$ the Second Circuit stated that the more generalized "deleterious effects which flow directly from a sullied reputation" do not alone suffice under Paul. $^{262}$ Such broad consequences:

${ }^{253}$ See supra notes 139-63 and accompanying text.

${ }^{256}$ See supra notes $168-208$ and accompanying text.

${ }^{27}$ Citing Paul one U.S. Department of Justice spokesperson recently stated that "simply labeling a person a 'criminal' or making statements that a person committed a particular crime does not infringe on a constitutional right, even if the information is not true and even if third parties rely on the information to refuse to employ or rent a residence to that person." See SACCO, supra note 252 , at 52.

${ }^{2 s}$ Neu v. Corcoran, 869 F.2d 662, 667 (2d Cir. 1989). See also Ersek v. Township of Springfield, 102 F.3d 79, 83 n.5 (3d Cir. 1996) (referring to "plus" as "uncertain").

${ }^{29}$ See supra notes $156-59$ and accompanying text.

${ }^{260}$ See Paul v. Davis, 424 U.S. 693, 697 (1976). See also Siegert v. Gilley, 500 U.S. 226, 234 (1991) (noting same); Phelps v. Wichita Eagle-Beacon, 886 F.2d 1262, 1269 (10th Cir. 1989) (deeming damage to future employment opportunities as "too intangible"); Tarkanian v. National Collegiate Athletic Ass'n, 741 P.2d 1345, 1350 (Nev. 1987) ("The stigma which satisfies the 'stigma-plus' in the employment context must be such that it forecloses plaintiff's employment to take advantage of other employment opportunities."); Levinsky v. Diamond, 559 A.2d 1073,1085 (Vt. 1989) (deeming alleged interference with prospective business operations as "too speculative").

Although the shoplifting charges against Davis were eventually dismissed, five years after the flyer incident he reported that he was "broke, without employment, emotionally sick and in a state of anxiety." See The Supreme Court, 1975 Term, supra note 96, at 100-01 n.85.

${ }^{261} 18$ F.3d 992 (2d Cir. 1994).

${ }^{262}$ Id. at 1001 . 
would normally include the impact that defamation might have on job prospects, or, for that matter, romantic aspirations, friendships, selfesteem, or any other typical consequences of a bad reputation. When the Supreme Court stated in Paul v. Davis that injury to reputation was not by itself a deprivation of a liberty interest, we presume that the Court included the normal repercussions of a poor reputation within that characterization.

In Valmonte, discussed above, appearance on the child abuse registry placed "a tangible burden" on the plaintiff, rather than "an intangible deleterious effect that flows from a bad reputation.,"264 This was because the New York law in fact imposed an additional "statutory impediment": it both required that potential employers consult the registry before hiring the plaintiff, and imposed the "added burden on employers" of providing a written justification if they wished to hire her. ${ }^{265}$ Because notification laws impose no such "added burden" on sex offenders, the very real, but still generalized, diminution in reputation they suffer in the job market (and society more generally) arguably does not satisfy the "plus" requirement. ${ }^{266}$ Moreover, despite the fact that government carries out the notification, and hence enables the harm accruing to registrants, difficulties arguably arise on the basis of decisions holding that the injurious "plus" must be caused directly by the government, not third parties such as employers. ${ }^{267}$ Finally, while the imposition of an ongoing duty to maintain registry status can be construed as an

${ }^{203} \mathrm{Id}$. See also Siegert, 500 U.S. at 234 ("plus" not satisfied if "damage flows directly from injury caused by the defendant to a plaintiff's reputation ..."); Mosrie v. Barry, 718 F.2d 1151, 1162 (D.C. Cir. 1983) (mere adverse public reaction does not constitute "plus").

${ }^{264}$ Valmonte, 18 F.3d at 1001. See also supra notes 210-13 and accompanying text.

${ }^{265}$ Valmonte, 18 F.3d at 1001.

${ }^{266}$ The Valmonte court was at pains to emphasize that the registry law posed a "unique situation" and noted that the Supreme Court has indicated "that perhaps only those who are defamed while in the course of being terminated from government employment can state a cause of action for deprivation of a liberty interest." Id. at 1002 (emphasis added) (citing Siegert, 500 U.S. at 241-42). Because the registry law required prospective employers to inform potential employees if they were denied a job because of inclusion in the registry, the Second Circuit did not "see much of a difference in the distinction between losing one's established position in government employment, and losing one's prospective position in government or a government-regulated field precisely because of the defamation." Id.

In Paul, although the plaintiff was not fired as a result of the flyer, he was expressly told by his supervisor that he "had best not find himself in a similar situation" again. Paul v. Davis, 424 U.S. 693,696 (1976).

${ }^{207}$ See, e.g., WMX Tech., Inc. v. Miller, 80 F.3d 1315, 1320 (9th Cir. 1996); Doe v. Kelley, 961 F. Supp. 1105, 1112 (W.D. Mich. 1997); Higginbotham v. King, 63 Cal. Rptr. 2d 114, 118 (Cal. Ct. App. 1997). 
added "tangible burden," 268 it is conceivable that the Court would regard this as a mere regulatory obligation, thus taking it outside due process concern.

Perhaps more problematic, for a governmental action to infringe the "reputation, honor, or integrity" of a person, it appears that the action must involve a publication that is substantially and materially false. ${ }^{270}$ Without a factual dispute that "has some bearing on the employee's reputation," the Court has held, the principal due process relief-a nameclearing hearing-would serve no useful purpose. ${ }^{271}$ This of course raises difficulty with respect to any claim that notification without notice or opportunity to be heard violates due process, as the underlying sex crime conviction in itself is not prone to factual dispute. Thus, arguably due process is not warranted despite the fact that it is the official governmental designation (e.g., "predator" or "compulsive" sex offender), not the predicate conviction qua conviction, that is so stigmatizing and harmful. ${ }^{272}$

${ }^{268}$ See supra notes $160-61$ and accompanying text.

${ }^{269}$ Indeed, the Ninth Circuit intimated as much in its recent holding that a sex offender subject to registration and community notification was not "in custody" for purposes of federal habeas corpus jurisdiction. See Williamson v. Gregoire, 151 F.3d 1180 (9th Cir. 1998), cert. denied, 119 S. Ct. 824 (1999). The burdens were a "collateral consequence of conviction rather than a restraint on liberty," and thus were a mere "civil regulation" akin to the loss of the right to vote, own firearms, or possess a professional license. Id. at 1183-84 (citing Russell v. Gregoire, 124 F.3d 1079, 1093 (9th Cir. 1997), cert. denied, 118 S. Ct. 1191 (1998)).

${ }^{270}$ See Codd v. Velger, 429 U.S. 624, 627-29 (1977).

${ }^{27} I d$. at 627 .

27 Justice Stevens, dissenting, addressed this concern in Codd, arguing that the majority's rule ignored the liberty interest in avoiding a "stigma or other disability that forecloses employment opportunities," which arise even if the basis for the stigma is technically true. Id. at $633 \mathrm{n.3}$ (Stevens, J., dissenting). Moreover, Justice Stevens reasoned, it is the "official determination, based on such information, that the employee is unfit for public employment" that was so damaging. Id. at 633 . A similar argument could be made with respect to notification, but would likely prove equally unsuccessful. See, e.g., Collie v. State, 710 So. 2d 1000, 1012 (Fla. Dist. Ct. App.) (rejecting argument that "sexual predator designation, by itself, infringes on [petitioner's] liberty rights" because law is "non-punitive and remedial in nature"), rel. denied, 722 So. 2d 192 (Fla.), cert. denied, 119 S. Ct. 624 (1998). Cf. Dean v. McWherter, 70 F.3d 43, 45-46 (6th Cir. 1995) (denying liberty interest claim arising out of a legislative finding that sex offenders constitute "a species of mentally ill persons in the eyes of the general assembly ...").

In this regard, it bears mention that pre-Paul cases, including Wisconsin v. Constantineau, conceived of the issue in terms of "stigma," "badge of infamy," or "branding," not defamation. See Randolph J. Haines, Note, Reputation, Stigma and Section 1983: The Lessons of Paul v. Davis, 30 STAN. L. REV. 191, 223-25 (1977). 
Finally, although a strong case can be made that both the "stigma" and "plus" are demonstrably more acute with notification, compared to the Paul facts, it is quite conceivable that the Court will conclude otherwise. For instance, in Paul the plaintiff, who had been arrested by private store security, not even police, and had only one prior arrest (for speeding), ultimately was not even prosecuted. ${ }^{273}$ Sex offender registrants, on the other hand, typically have been adjudicated guilty, removing from the analysis the presumption of innocence, which surely influences any perception of procedural unfairness. ${ }^{274}$ Also, the classification processes used by states to make registration and notification decisions might not give the Court pause. Indeed, the Paul majority found solace in the fact that the decision to brand the plaintiff as an "active shoplifter" was made informally by local police, not any official adjudicative body, raising a likelihood that the Court will similarly find that the compulsory or otherwise informal, law-enforcement dominated processes used in most states today will pass muster under Chief Justice Rehnquist's leadership. ${ }^{27}$

${ }^{273}$ See Paul v. Davis, 424 U.S. 693, 718-19 (1976) (Brennan, J., dissenting). In Valmonte, discussed supra, where the Second Circuit found a deprivation of "liberty" in relation to placement on a child abuse registry, the plaintiff was also ultimately exonerated. See Valmonte v. Bane, 18 F.3d 992, 1001 (2d Cir. 1994). See also supra notes 261-69 and accompanying text.

${ }^{274}$ See Paul, 424 U.S. at 725 n.12 (Brennan, J., dissenting) (emphasizing with respect to the majority's stance that " $[i] t$ is hard to conceive of a more devastating flouting of the presumption of innocence ..."). With apparent disdain for the Paul majority's holding, Justice Brennan added:

It is inexplicable how the Court can say that a person's status is "altered" when the State suspends him from school, revokes his driver's license, fires him from a job, or denies him the right to purchase a drink of alcohol, but is in no way "altered" when it officially pins upon him the brand of a criminal, particularly since the Court recognizes how deleterious will be the consequences that inevitably flow from its official act.

Id. at 734 .

${ }^{275}$ In Paul Justice Rehnquist distinguished Jenkins v. McKeithen, where the Court struck down a Louisiana commission dedicated to the formal branding of citizens as criminals without due process. See Paul, 424 U.S. at 706 n.4 (discussing Jenkins v. McKeithen, 395 U.S. 411 (1969)). By comparison, the informal evaluative acts undertaken by the police in Paul " $f[e] 11$ far short of the more formalized proceedings" that compel due process protections. Id. The police were "not by any conceivable stretch of the imagination ... 'an agency whose sole or predominant function, without serving any other public interest, is to expose and publicize the names of persons it finds guilty of wrongdoing.'" Id. (quoting Jenkins, 395 U.S. at 438 (Harlan, J. dissenting)).

Why this relative informality should be significant is unclear. As Justice Brennan trenchantly, and presciently, offered in his Pauldissent:

The logical and disturbing corollary of this holding is that no due process infirmities would inhere in a statute constituting a commission to conduct ex parte trials of individuals, so long as the only official judgment pronounced was limited to public condemnation 
None of the foregoing is intended to defend Paul; its result, as Justice Brennan noted in dissent, is "frightening for a free people," ${ }^{276}$ and the majority's distinction of precedent, most notably Constantineau, surely numbers among the worst instances of judicial speciousness. ${ }^{277}$ In the end, however, while it is apparent that Paul in significant part can be explained by the Court's fear that a decision in favor of the plaintiff would have led to a complete federalization of state tort law on the basis of Section $1983,{ }^{278}$ there is little hope that the current Court will reverse $\mathrm{Paul}$ or renounce its fundamentally narrow and positivist view of liberty. Despite Justice Brennan's caustic surmise in Paul that "today's decision must surely be a short-lived aberration,"

and branding of a person as a Communist, a traitor, an "active murderer," a homosexual, or any other mark that "merely" carries social opprobrium. The potential of today's decision is frightening for a free people.

Id. at 721 (Brennan, J., dissenting).

Indeed, regardless of the decision-making mechanism, the fact remains that action by the sovereign carries a recognized imprimatur. This imprimatur itself "usually implies that the information at issue has been tried and tested according to the dictates of due process." Shearer v. Leuenberger, 591 N.W.2d 762, 777 (Neb. 1999) (Connolly, J., concurring). See also id. (describing Paulfacts as involving "obviously makeshift postings of local law enforcement").

${ }^{276}$ Paul, 424 U.S. at 721 (Brennan, J., dissenting).

2m See, e.g., TRIBE, supra note 55, $\$ 10-11$, at 702 ("[T] he Court in Constantineau rested its holding only on the fact that 'a person's good name, reputation, honor, or integrity is at stake because of what the government is doing to him.' And both Board of Regents $v$. Roth and Goss $v$. Lopez reiterated this formulation of the "core' interest in reputation.") (citations omitted) (emphasis in original). See also Haines, supra note 272, at 217-23 (surveying cases prior to Paul that "demonstrate the development of a constitutional tort doctrine focusing on governmental stigmatization").

${ }^{273}$ See Paul, 424 U.S. at 697 (expressing fear that allowing plaintiff's suit under Section 1983 "would seem almost necessarily to result in every legally cognizable injury which may have been inflicted by a state official ... establishing a violation of the Fourteenth Amendment"). Commentators have noted the same. See, e.g., TRIBE, supra note 55, § 10-11, at 704; Armacost, supra note 93, at 576-78; Monaghan, supra note 93, at 423-34. According to Professor Monaghan: "[T]he pressure to keep [such] cases out of the federal courts was great, and so a compromise was struck ... . [T] he courts struck a compromise at the definitional stage." Id. at 429.

The New Jersey Supreme Court, addressing a non-Section 1983 claim that the State's notification law implicated a liberty interest and violated due process, has distinguished Paul on this basis. See Doe v. Poritz, 662 A.2d 367, 418 n.26 (N.J. 1995) ("Finding a protectible interest in this case would not risk federalizing tort law. Plaintiff's claim is not a state defamation action. We are not dealing here with random disclosures, but with systematic disclosures following ex parte classification by local prosecutors.").

${ }^{279}$ Paul, 424 U.S. at 735 (Brennan, J., dissenting).

Justice Brennan further worried that in the wake of $\mathrm{Paul}^{\text {" }}[\mathrm{i}] \mathrm{t}$ is not difficult to conceive of a police department ... publishing periodic lists of 'active rapists,' 'active larcenists,' or other "known criminals." Id. at 721 n.9. In addition to the striking resemblance such a premonition has to the current registration and notification laws, it is apparent that Pauls constitutional carte blanche is being taken to heart by local police departments in the very way envisioned by Justice Brennan. See 20/20 (ABC television broadcast, Oct. 18, 1996) (featuring Massachusetts police chief who broadcasts the names and photos of selected arrestees as "punk of the week" or "toilet 
and the questionable need for the Court to render reputation (i.e., the right to be free of unwarranted official "branding") a constitutional superfluity, ${ }^{280}$ over twenty years later it remains a guiding precedent in the liberty interest analysis.

\section{B. THE SHRINKING SPECTRUM OF PROTECTIBLE LIBERTY}

The question of whether sex offender registrants enjoy a constitutional right to privacy, as noted above, can play a critical role in the liberty analysis. ${ }^{281}$ Indeed, the Ninth Circuit and several other courts have held that the lack of any protectible privacy interest against the disclosure of otherwise "public" information dictates a corollary absence of a protectible federal liberty interest, ruling out the need for due process. ${ }^{282}$ On the other hand, the recognition of such an interest has played a lynchpin role in the decisions of numerous other courts in favor of finding that due process must be accorded. ${ }^{283}$ Although such courts have a sound basis for their holdings, the trajectory of the Supreme Court's decisions in recent years makes such a libertyaffirming outcome unlikely. ${ }^{284}$

licking maggots"). Compare Benjamin Weiser, Joumalists Fear Ruling Could Hinder Coverage of the Police, N.Y. TIMES, Feb. 27, 1999, at B2 (discussing recent ruling by federal district court that barred "perp walks" for the benefit of the press, on the rationale that it invaded privacy rights of suspects).

${ }^{200}$ As Professor Barbara Armacost recently noted, "[t]he tort-like quality of the plaintiff's injury in Paul is irrelevant to the question of whether the harm also implicates a constitutional right." Armacost, supra note 93, at 581. In other words, rather than conceiving of the Paul claim as a generic state tort claim, with its implicit "floodgates" concern, the inherent constitutional quality of the claim in Paul warranted address. See id at 575 ("[T] he injury to reputation at issue in Paul is exactly the kind of claim that ought to be governed by federal constitutional law rather than state law."). Indeed, courts interpreting Paul have required that an ancillary, already constitutionally protected interest (typically property) be jeopardized for a constitutional claim to arise. See, e.g., Peters v. Houston, No. Civ. 98-1580, 1999 WL 554581, *13 (E.D. Pa. July 13, 1999) (" $[\mathrm{A}]$ property interest conjoined with reputational interests can satisfy the requirements of the due process clause."); Boylan v. Arruda, 42 F. Supp. 2d 352, 358 (S.D.N.Y. 1999) ("[The added harm] takes the plaintiff's claim out of the realm of the merely defamatory and transforms it into a case of truly constitutional dimension."). Given this additional constitutional prerequisite, one is obliged to ask why "stigma" is required at all.

${ }^{201}$ See supra notes $105-43$ and accompanying text. See also Lawrence Alexander, The Relationship Between Procedural Due Process and Substantive Constitutional Rights, 39 U. FLA. L. REv. 323, 324 (1987) ("' $[L]$ ife, liberty, and property' are best thought of as referring to all interests the deprivation of which can implicate substantive constitutional values.").

${ }^{202}$ See supra notes $105-43$ and accompanying text.

2as See supra notes 151-62 and accompanying text.

${ }^{23}$ As noted by one commentator:

[E]ven when the Court has confronted problems that most people would categorize under the general heading of privacy ... it has tended to avoid the privacy label when it intended 
Indeed, although for the better part of the twentieth century "liberty" has been expansively defined by the Supreme Court, ${ }^{285}$ the Court in recent years has sharply limited the scope of protectible interests deemed sufficient to trigger due process. ${ }^{286}$ Commentators have concluded that we are in the midst of a due process "counterrevolution," vistic return to a narrow definition of constitutionally protectible "liberty." 288

The origins of this retrenchment by most accounts are found in a series of the Court's decisions in the 1970s. In cases such as Meachum v. Fano, ${ }^{289}$ Bishop v. Wood, ${ }^{290}$ and Board of Regents

to uphold the regulation .... [I]n Paul v. Davis, the Court held that an unsullied reputation was not a specially protected liberty interest by summarily categorizing it as outside the "right to privacy."

David Crump, How Do the Courts Really Discover Unenumerated Fundamental Rights? Cataloguing the Methods of Judicial Alchemy, 19 HARV. J.L. \& PUB. POL'Y 795, 893 (1996) (footnote omitted).

${ }^{255}$ In 1923, the Court stated that "liberty":

denotes not merely freedom from bodily restraint but also the right of the individual to contract, to engage in any of the common occupations of life. To acquire useful knowledge, to marry, establish a home and bring up children, to worship God according to the dictates of his own conscience, and generally to enjoy those privileges long recognized at common law as essential to the orderly pursuit of happiness by free men.

Meyer v. Nebraska, 262 U.S. 390, 399 (1923). Seven years earlier, in 1916, the Court unequivocally stated that "liberty" "was intended to preserve and protect fundamental rights long recognized under the common law system." Butler v. Perry, 240 U.S. 328, 333 (1916).

${ }^{285}$ See ROTUNDA \& NOWAK, supra note $99, \S 17.2$, at 7 ("Since 1972 a majority of the justices have chosen to take quite literally, and restrictively, the concept that due process applies only to 'life, liberty or property.' In recent years the decisions have narrowly construed these terms ... . ); TRIBE, supra note 55, \$10-10, at 694 (noting the "considerable narrowing of the liberty and property interests protected by procedural due process"). Numerous other commentators have noted the same retrenchment. See, e.g., Gelman, supra note 93; Monaghan, supra note 93; William Van Alstyne, Cracks in "The New Property": Adjudicative Due Process in the Administrative State, 62 CORNELI. L. REV. 445 (1977).

${ }^{287}$ See Pierce, supra note 93. See also Rebecca E. Zietlow, Giving Substance to Process: Countering the Due Process Counterrevolution, 75 DEN. U. L. REv. 1, 32 (1997) ("In recent years, this country has undergone a due process counterrevolution, in which courts and legislatures have restricted the due process rights that they once had expanded thirty years ago.") (footnote omitted).

${ }^{288}$ See Monaghan, supra note 93, at 411-14 (discussing the Court's evolution away from a broad view of "liberty" to one predominantly focusing on physical or "locomotion" liberty, last popular in the eighteenth and nineteenth centuries). Professor Monaghan persuasively argues that the retreat from a "latitudinarian approach to 'liberty' and 'property" stems in large part from the conservative fear of a proliferation of constitutional claims brought pursuant to 42 U.S.C. $\$ 1983$. Id. at 408 . With the Fourteenth Amendment looming, "statutory explication necessarily becomes constitutional exegesis as well." Id.

${ }^{299} 427$ U.S. 215, 223-24 (1976) (holding that state prisoner has no "liberty" interest in avoiding transfer to a more restrictive prison setting).

${ }^{20} 426$ U.S. 341,348 (1976) (rejecting claim that non-probationary public employee has "liberty" or "property" interest in continued employment). 
v. Roth, ${ }^{291}$ the Court manifested its preference for narrowness, a view more recently characterized by the core belief that liberty encompasses little more than literal "freedom from physical restraint." ${ }^{292}$ At the same time, as Charles Miller had recognized, due process emphasis has shifted from protecting individual rights to protecting the community at large. ${ }^{293}$ This general shift has obvious importance to the evaluation of sex offender notification laws, which seek to protect the community by imposing restraints on registrants-restraints of a distinctly phenomenological, if not physical, nature.

Another important trend is the Court's disinclination to extend due process rights to those already convicted of crimes. Without question, duly convicted criminal defendants suffer a diminished expectation of due process rights. As Justice O'Connor has observed, "[o]nce society has validly convicted an individual of a crime and therefore established its right to punish, the demands of due process are reduced accordingly."294 This said, however, the Court's decisions evince a decided tendency to conceive of this already reduced due process expectation in the narrowest possible terms. ${ }^{295}$ For instance, in Meachum v. Fano, ${ }^{296}$ a 1976 decision involving a due process challenge to the adequacy of state procedures pertaining to prisoners' transfer to a more restrictive setting, the Court made clear that, although the "convicted felon does not forfeit all constitutional

${ }^{201} 408$ U.S. 564, 570 (1971) (stating that while "the range of interests protected by procedural due process [is] broad indeed," it is "not infinite").

${ }^{202}$ See, e.g., Kansas v. Hendricks, 521 U.S. 346, 356 (1997) ( $[$ [F]reedom from physical restraint 'has always been at the core of the liberty protected by the Due Process Clause." ); Foucha v. Louisiana, 504 U.S. 71, 80 (1992) ("Freedom from bodily restraint has always been at the core of liberty protected by the Due Process Clause from arbitrary governmental action."); Youngberg v. Romeo, 457 U.S. 307, 316 (1982) ("Liberty from bodily restraint has always been recognized as the core of the liberty protected by the Due Process Clause."). Compare Meyer v. Nebraska, 262 U.S. 390, 399 (1923) ("[Liberty] denotes not merely freedom from bodily restraint ... . "); Allgeyer v. Louisiana, 165 U.S. 578, 589 (1897) (rejecting idea that liberty embraces "only the right of the citizen to be free from the mere physical restraint of his person").

${ }^{235}$ See Charles Miller, The Forest of Due Process of Law: The American Constitutional Tradition, in NOMOS XVIIY: DUE Process 3 (J. Roland Pennock \& John W. Chapman eds., 1977).

${ }^{24}$ Ford v. Wainwright, 477 U.S. 399, 429 (1986) (O'Connor, J., concurring in result in part and dissenting in part).

${ }^{205}$ Speaking of the counterrevolution, one commentator has singled out prisoners' rights as an area of due process "terrain" that heretofore "had been fully occupied and fortified by the revolutionary forces." Pierce, supra note 93, at 1988.

206 U.S. 215 (1976). 
protections," ${ }^{297}$ any generalized liberty a prisoner might have as to his place of confinement was extinguished upon lawful conviction. ${ }^{298}$ Likewise, in Connecticut Board of Parsons v. Dumschat, ${ }^{299}$ the Court concluded that a State's refusal to provide a rationale for its rejection of an inmate's petition to commute his life sentence did not affect a liberty deprivation because the interest at stake (i.e., against continued confinement) was already extinguished. Dumschat labored under "simply a unilateral hope" that liberty would be restored, which itself is not deserving of protection. $^{300}$

In its 1995 decision in Sandin $v$. Conner, ${ }^{301}$ the Court held that inmates are not deprived of a liberty interest when subjected to a thirty-day term in solitary confinement because of previous "high misconduct." In so doing, the five-member majority distanced itself from an extended series of decisions over the preceding twenty years tying liberty to the existence of prison rules, ${ }^{302}$ concluding that the series had "strayed from the real concerns undergirding the liberty protected by the Due Process Clause." from physical restraint which ... [also] imposes atypical or significant hardship on the inmate in relation to the normal incidents of prison life." 304

A case from the Court's 1998 term, Ohio Adult Parole Authority $v$. Woodard, ${ }^{305}$ especially highlights the Court's narrow conception of post-conviction liberty. In Woodard, the Court

${ }^{297} I d$. at 225.

$\approx$ Id. at 229 .

299 U.S. 458,461 (1981).

500 Id. at 465 . Compare Greenholtz v. Inmates of Nebraska Penal \& Correctional Complex, 442 U.S. 1, 9 (1979) (holding that, in the absence of State law expressly creating such an expectation, availability of parole provides a prisoner "no more than a mere hope that the benefit will be obtained") with Morrissey v. Brewer, 408 U.S. 471, 482 (1972) (stating that ex-convicts facing revocation of parolee status have a protectible "conditional" liberty interest).

${ }^{301} 515$ U.S. 472 (1995). According to Richard Pierce, Sandin was "the first of a series of counterrevolutionary decisions that will have effects as wide-ranging as those of the revolutionary decisions issued between 1970 and $1972 \ldots$. . By the turn of the century, the due process revolution of the 1970s will be relegated to a chapter in a legal history book." See Pierce, supra note 93 , at 1989.

${ }^{302}$ See, e.g., Kentucky Dep't of Corrections v. Thompson, 490 U.S. 454 (1989); Hewitt v. Helms, 459 U.S. 460 (1983); Wolff v. McDonnell, 418 U.S. 539 (1974).

${ }^{303}$ Sandin, 515 U.S. at 483.

sor Id.

${ }^{303} 118$ S. Ct. 1244 (1998). 
addressed the question of whether an Ohio death row inmate, whose rights to appeal had been exhausted, was deprived of due process as a result of the State's clemency procedures. ${ }^{306}$ Focusing on whether Woodard enjoyed a "life" interest sufficient to trigger due process, ${ }^{307}$ eight justices concluded that no due process violation occurred, ${ }^{308}$ but in a highly fractured plurality opinion.

Writing for himself and Justices Scalia, Kennedy, and Thomas, Chief Justice Rehnquist stated that Woodard had only a "unilateral hope" of clemency; ${ }^{309}$ anything else had been extinguished by his conviction and death sentence. ${ }^{310}$ According to the Chief Justice, "there is no continuum [of due process rights] requiring varying levels of process at every conceivable phase of the criminal system." Asil Aside from retaining a very modest "residual life interest, e.g., in not being summarily executed by prison guards," 312 any entitlement to due process, once extin-

${ }^{500}$ In particular, Woodard claimed that the State's provision of a voluntary clemency interview was improper. Rather than request an interview, as he was directed by the State to do if he wished one to take place, Woodard instead objected to the short notice of the interview, and "requested assurances that counsel could attend and participate in the interview" and subsequent clemency hearing. Id. at 1248.

${ }^{507}$ Id. at 1249. The Court's focus on "life," given Woodard's impending possible execution, is both logical and consistent with its view that his "liberty" had been extinguished (even if afforded clemency, Woodard would remain in prison). Nevertheless, the Court's focus on "life" is rare and arguably significant. See Daniel T. Kobil, Due Process in Death Penalty Commutations: Life, Liberty, and the Pursuit of Clemengy, 27 U. RICH. L. REV. 201, 217 (1993) ("[T]he Court has omitted mention of the protection of life from most discussions of procedural due process.").

${ }^{306}$ Woodard, $118 \mathrm{~S}$. Ct. at 1252 (plurality opinion).

The Court also addressed, and unanimously rejected, Woodard's claim that his Fifth Amendment right against self-incrimination was violated when he was barred from receiving immunity for any incriminating statements he might make at a voluntary interview before the Clemency Authority. Id. at 1253. Writing for the Court, Chief Justice Rehnquist reasoned that because the interview was voluntary, the Fifth Amendment's bar against "compelled" selfincrimination was not applicable. Id. Although it might have been in Woodard's strong selfinterest to have an interview, the State did not force him to do so. Id.

${ }^{509}$ Id. at 1250.

${ }^{310}$ The Chief Justice also concluded that the State's clemency procedures themselves did not create a protectible due process interest. Id. at 1251-52. Despite the mandatory nature of the procedures, Woodard had only a minimal expectation of clemency, itself undercut by the broad discretion the Governor enjoyed in the clemency decision. Id. at 1251.

slt Id. The Chief Justice rejected Woodard's claim that such a continuum exists on the basis of Evitts $v$. Lucey, where the Court held that criminal defendants have a right to effective assistance of counsel in their first appeal as a matter of right. Id. (discussing Evitts v. Lucey, 469 U.S. 387, 394-96 (1985)). He reasoned that the discretionary nature of clemency differed from the mandatory right of appeal in Evitts, and concluded that "clemency is [not] an integral part of Ohio's system of adjudicating the guilt or innocence of the defendant." Id.

${ }^{312}$ Id. at 1250. 
guished, can be regained only under limited circumstances. By way of example, the plurality offered Ford $v$. Wainwright, where the Court held that the Eighth Amendment bars execution of the insane, because the "protected [liberty] interest . . . arose subsequent to trial, and was separate from the life interest already adjudicated in the inmate's conviction and sentence. This interest therefore had not been afforded due process protection."

Justice O'Connor concurred in the result, with Justices Ginsburg, Souter, and Breyer joining her. Although she concluded that the process Woodard received, including notice and an opportunity to participate in the interview, satisfied due process, she and her fellow concurring justices were at pains to state that "it is incorrect . . . to say that a prisoner has been deprived of all interest in his life before his execution." "314 Justice Stevens, the sole dissenter, stated that the Court lacked a sufficient evidentiary record to assess whether due process was afforded, and adamantly disagreed with the Chief Justice's assertion that "there is no continuum requiring varying levels of process at every ... phase of the criminal justice system." "315

Taken together, the decisions discussed above surely do not favor any positive determination by the present Court that notification implicates a protectible liberty interest warranting due process. The plain disinclination of the Court to conceive of reputation as a liberty interest, ${ }^{316}$ the Court's uncertain stance with respect to any constitutional right to informational privacy, ${ }^{317}$ and the apparent view of a near-majority of justices that "there is no continuum [of due process rights] requiring varying levels of process at every conceivable phase of the criminal ring)).

${ }^{31 s}$ Id. at 1250 n.3 (citing Ford v. Wainwright, 477 U.S. 399, 425 (1986) (Powell, J., concur-

${ }_{314}^{14}$ Id. at 1254 (O'Connor, J., concurring) (emphasis added).

${ }^{315}$ Id. at 1254, 1255-56 n.3 (Stevens, J., dissenting in part).

${ }^{316}$ See Paul v. Davis, 424 U.S. 693, 701 (1996) ("The words 'liberty' and 'property' as used in the Fourteenth Amendment do not in terms single out reputation as a candidate for special protection ...."). See also Siegert v. Gilley, 500 U.S. 226, 233-84 (1991) (noting same); ROTUNDA \& NowAK, supra note $99, \S 17.4$, at 65 ("One of the most disputed aspects of liberty in recent years is the degree to which the due process clauses protect the interest of an individual in his reputation.").

${ }^{317}$ See supra notes $56-73$ and accompanying text. 
system,"318 all militate against an affirmative finding. Furthermore, although notification profoundly taints the community standing of targeted individuals, and harms them in manifold other ways, ${ }^{319}$ the fact that notification imposes no physical restraint per se, makes the procedural due process analysis all the bleaker.

\section{CONCLUSION}

All free societies, most certainly our own, must decide whether, and to what extent, those they fear are to be accorded liberties. ${ }^{320}$ This dilemma is surely evident with respect to sex offenders who, although they have paid their debt to society as a result of incarceration, remain the subject of profound fear and disdain. $^{321}$ The proliferation of sex offender notification laws signifies Americans' clear preference for community protection at the expense of the liberty interests of sex offenders: the laws seek to preempt sex crimes by at once branding offenders and providing information to communities in the putative name of public safety through self-protection. ${ }^{322}$ Viewed in historical context, notification laws at once evidence the catalytic effects of "moral panic," a phenomenon first recognized by sociologist

"Woodard, 118 S. Ct. at 1251.

That at least four members of the Court should adopt such a narrow view of protectible interest in the context of the death penalty is itself telling. Indeed, true to the "extinction" principle of the post-conviction right set forth in Dumschat and Meachum, the Chief Justice apparently believes that Woodard lost his "life" interest at the moment his death sentence was imposed. See id. at 1252 n.5.

${ }^{319}$ See Roe v. Farwell, 999 F. Supp. 174, 197 (D. Mass. 1998) (characterizing the interest at stake as one in "avoiding 'the statutory branding of [petitioner] as a public danger,' and its attendant impact on his reputation, employment opportunities, and ability to control the disclosure of personal information").

${ }_{320}$ Ten years ago one commentator observed: "[a]s America moves into the twenty-first century, we must determine to what extent individual liberties must be sacrificed for the common good. Ideals of liberty and privacy are stretched to the limit as modern fears of street crime merge with ancient fears of plague." Edward P. Richards, The Jurisprudence of Prevention: The Right of Societal Self-Defense Against Dangerous Individuals, 16 HASTINGS CONST. L.Q. 329, 329 (1989).

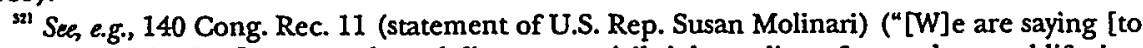
released sex offenders] yes, you then abdicate your civil rights to live a free and normal life, just like your victim did at the moment that the crime was committed.").

${ }^{\prime \prime}$ See Telpner, supra note 14, at 2068 ("The main purpose of these laws cannot be merely to prevent future crimes. Rather, by denouncing released sex offenders, these laws satisfy the community's social and emotional need to define itself in a way that excludes these offenders."). 
Edwin Sutherland fifty years ago, ${ }^{323}$ and resemble methods of social control last employed in the American West of the mid1800s. This time, however, we have "unwanted posters"-which specify where the target of fear resides and perhaps works. ${ }^{324}$

Ultimately, the affirmative legislative decision that state and federal governments have made to require community notification may prove a socially responsible one. Sex offenses indisputably cause enormous physical and emotional harm, and making registrants' identifying information publicly available apparently provides Americans with some measure of psychic comfort. But whatever their merits, notification laws do come at a cost; the highly personal information they convey, and the official stigmatization they foster, have obvious and unavoidable effects on the liberty interests of those targeted-and possibly for their entire lives. ${ }^{325}$ In a society that exalts the "right to be let alone" as the "right most valued by civilized men,"326 affording due process prior to community notification would appear a constitutional certitude. However, given the shrinking spectrum of liberty interests identified by the Supreme Court in the last two decades, and the uncertain outlines of its informational privacy and reputational interest jurisprudence, it is unlikely that a majority of the present Court will agree. This is especially so given the enduring bogeyman status of sex offenders and the court's historic deference to the police power of states to exercise social control over them. ${ }^{327}$

Nevertheless, an alternative avenue does perhaps exist: state constitutions-a "font of individual liberties," as Justice Brennan

${ }^{323}$ Edwin H. Sutherland, The Diffusion of Sextual Psychopath Laws, 56 AM. J. Soc. 142 (1950). Although Sutherland did not use the phrase "moral panic," his recognition of the "hysteria" driving sex psychopath laws was instrumental in the conceptualization of the phenomenon. See Michael Tonry, Rethinking Unthinkable Punishment Policies in America, 46 UCLA L. REV. 1728, 178186 (1999) (surveying development of "moral panic" theory).

${ }^{324}$ See W.P. v. Poritz, 931 F. Supp. 1199, 1217 \& n.20 (D. N.J. 1996), reu'd on other grounds sub nom. E.B. v. Verniero, 119 F.3d 1077 (1997) (noting same).

${ }^{325}$ As Seth Kreimer has noted: “[n]o one doubts that Hester Prynne's scarlet letter provided more than neutral information, or that the effort of Senator Joseph McCarthy to 'expose' the background of his political opponents was not simply public education." Seth F. Kreimer, Sunlight, Secrets, and Scarlet Letters: The Tension Between Privacy and Disclosure in Constitutional Lawv, 140 U. PA. L. REV. 1, 7 (1991) (footnote omitted).

${ }^{226}$ See Olmstead v. United States, 277 U.S. 438, 478 (1928) (Brandeis, J., dissenting).

${ }^{327}$ See supra notes $2-3$ and accompanying text. 
once collectively referred to them. ${ }^{328}$ Although closely related to their federal counterpart, state constitutions can, and often do, provide more and different protections to state citizens, ${ }^{329}$ in effect providing a "double security." "330

Indeed, state constitutions often contain unique provisions designed to favor citizens' civil liberties, which on their face protect "reputation"331 and "privacy," sweeping provisions that admit of broad interpretation. ${ }^{333}$ This richness derives as much from the individual historical identities of states, and their constitutions, ${ }^{334}$ as from the fundamental

${ }^{128}$ William J. Brennan, Jr., State Constitutions and the Protection of Individual Rights, 90 HARV. L. REV. 489, 491 (1977).

529 See id. (noting that state constitutional "protections often extend[] beyond those required by the Supreme Court's interpretation of federal law"). See also Jennifer Friesen, State Courts as Sources of Constitutional Law: How to Become Independently Wealthy, 72 NOTRE DAME L. REv. 1065, 1073 (1997) (citing numerous examples). See generally G. AlAN TARR, UNDERSTANDING STATE CONSTITUTIONS (1998).

${ }^{30}$ The phrase derives from James Madison who wrote in full:

In the compound republic of America, the power surrendered by the people is first divided between two distinct governments, and then the portion allocated to each subdivided among distinct and separate departments. Hence a double security arises to the rights of the people. The different governments will control each other, at the same time each will be controlled by itself.

The Federalist No. 51, at 164 (James Madison) (Bantam Books ed. 1982). But see Robert M. Cover, The Uses of Jurisdictional Redundancy: Interesh, Ideology, and Innovation, 22 WM. \& MARY L. REv. 639, 674-80 (1981) (noting that such redundancy can result in "confirmatory" or "nonconfirmatory" outcomes).

${ }^{311}$ See, e.g., ALA. CONST. art. I, § 13 ("[E]very person, for any injury done him, in his lands, goods, person, or reputation, shall have a remedy by due process of law ...."); ARK. CONST. art. $2, \S 2$ ("All men ... have certain inherent and inalienable rights, amongst which are those of... acquiring, possessing and protecting property and reputation ...."); CONN. CONST. art. I, $\$ 10$ ("All courts shall be open, and every person, for an injury done to him in his person, property or reputation, shall have remedy by due course of law ...."); DEL. CONST. Preamble ( $[$ [A]11 men have by nature the rights of ... acquiring and protecting reputation and property ...."); PA. CONST. art. I, $\$ 1$ ("All men ... have certain inherent and indefeasible rights, among which are those of ... acquiring, possessing and protecting property and reputation ....").

${ }^{32}$ See, e.g., MONT. CONST. art. II, $\$ 10$ ("The right of individual privacy is essential to the wellbeing of a free society...."); Campbell v. Sundquist, 926 S.W.2d 250, 261 (Tenn. Ct. App. 1996) ("[T]he right to privacy provided to Tennesseans under our Constitution is in fact more extensive than the corresponding right to privacy provided by the Federal Constitution."). See generally Ken Gormley \& Rhonda G. Hartman, Privacy and the States, 65 TEMP. L. REv. 1279 (1992).

ss See, e.g., N.M. CONST. art. II, § 4 (extending a fundamental right of "seeking and obtaining health and happiness"). See also State v. Yoskowitz, 563 A.2d 1, 13-15 (N.J. 1989) (discussing State's "faimess and rightness" doctrine).

${ }^{\text {ss }}$ See George P. Fletcher, Constitutional Identity, 14 CARDOZO L. REV. 737 (1993) (discussing the concept of constitutional identity). As New York Court of Appeals Chief Judge Judith Kaye has remarked: "the history that has shaped the values of this State is different in many respects from that which shaped the consensus in other states, not to mention our nation as a whole. Many states today espouse cultural values distinctively their own." Judith S. Kaye, Dual Constilutionalism in Practice and Principle, 61 Sr. JOHN's L. REv. 399, 423 (1987). 


\section{animating ideal of federalism itself. ${ }^{385}$ As one commentator re- cently noted:}

Independent interpretation by state courts of their state constitutions is important because it returns states to their original role of protecting the rights of the people in their states, fulfills the role of state courts as interpreters of their state charters and has the potential for increasing the importance of state court contributions to constitutional discourse where state courts take approaches which differ from federal constitutional analysis.

Consistent with this perspective, the highest courts of New Jersey $^{337}$ and Massachusetts ${ }^{338}$ have recently invoked their respective State constitutions to afford procedural protections in the

For similar sentiments expressed by other state appellate jurists see State v. Hunt, 450 A.2d 952, 967 (N.J. 1982) (Handler, J., concurring) ("[D]istinctive and identifiable attributes of a state government, its laws, and its people justify recourse to the state constitution as an independent source for recognizing and protecting individual rights."); Shirley S. Abrahamson, Reincamation of State Courts, 36 SW. L.J. 951, 965 (1982) (interpretation must take account of a state's "land, its industry, its people, its history"). See generally A.E. Dick Howard, The Renaissance of State Constitutional Lazw, 1 EMERGING IsSUES ST. CONST. L. I, 14 (1988) ("A state constitution is a fit place for the people of a state to record their moral values, their definition of justice, their hopes for the common good."); Randall T. Shepard, The Maturing Nature of State Constitution Jurisprudence, 30 VAL. L. REV. 421, 436-40 (1996) (discussing "meaningful differences" among states that account for varied constitutional outcomes).

For a vigorous defense of this "values-based" orientation toward state constitutional interpretation see Robert Schapiro, Identity and Interpretation in State Constitutional Law, 84 VA. L. REv. 389 (1998).

sss Although over the past century the federal courts have served as principal guardians of individual rights, it remains a historical verity that the state constitutions were first in existence, and at once served as models for the U.S. Constitution and lessened the perceived need for "the addition of an arguably superfluous Bill of Rights to the Federal Constitution." Ellen A. Peters, Capacity and Respect: A Perspective on the Historic Role of the State Courts in the Federal System, 73 N.Y.U. L. REv. 1065, 1073 (1998). Indeed, for a significant part of our nation's history, the federal Bill of Rights was deemed not binding on state courts. See id. at 1075-77 (describing how state courts during this era stepped in and filled the rights breach for citizens).

${ }^{36}$ Rachel A. Van Cleave, State Constitutional Interpretation and Methodology, 28 N.M. L. REv. 199, 201 (1998).

${ }^{357}$ In Doe v. Porits, the court found a protectible liberty interest to be at stake under both the New Jersey and U.S. Constitutions, but under different rationales. 662 A.2d 367 (N.J. 1995). As for federal law, the Poritz court found the Paul "stigma-plus" test satisfied, with the "plus" being the privacy invasion attending notification. Id. at 419. The court then turned to the New Jersey Constitution and inferred that two liberty interests were at risk: privacy and reputation. Significantly, under New Jersey constitutional law, there exists "a protectible interest in reputation without any other tangible loss." Id. (citing cases interpreting Article I, para. I of the New Jersey Constitution). In words strikingly similar to those used in Constantinear the court stated: "Where a person's good name or reputation are at stake because of what the government is doing to that person, we conclude, sufficient constitutional interests are at stake." Id. at 420 . See Wisconsin v. Constantineau, 400 U.S. 433,437 (1971).

sss In Doe v. Attomey General, the Supreme Judicial Court found a liberty interest under Article 12 of the Massachusetts Declaration of Rights, thus requiring due process before registration and notification, "without regard to whether such a person has an independent federally protected liberty or property interest." 686 N.E.2d 1007, 1012, 1013 n.8 (Mass. 1997). 
notification context, when their respective legislatures initially failed to provide sufficient pre-notification protections. ${ }^{339}$ Federal courts have likewise looked to indigenous state constitutional provisions to discern protectible liberty interests and require additional pre-notification procedural protections. ${ }^{340}$

In the end, although the question of how sex offenders are to be handled is initially a legislative prerogative, the judiciaryand state courts in particular-must inevitability play a central oversight role in protecting against legislative overgeneralization. ${ }^{341}$ The current wave of sex offender notification laws, however, perhaps carries promise for additional constitutional drama. In a palpable effort to inoculate the laws from constitutional challenge, numerous state legislatures, as part of their "legislative findings" attending enactment of registration and notification laws, have expressly stated that registrants have a "lessened expectation of privacy." ${ }^{342}$ The Florida Legislature,

so Similarly, the Minnesota Court of Appeals has invoked the Remedies Clause of its State Constitution to infer existence of a liberty interest when the Minnesota notification law granted officials immunity, thereby satisfying the "plus" requirement of Paul See In re C.M., 578 N.W.2d 391, 397 (Minn. Ct. App. 1998). See also supra notes 163, 205-08 and accompanying text (discussing state constitutional provisions regarding access to courts and remedies).

${ }^{50}$ See E.B. v. Verniero, 119 F.3d 1077, 1105 (3d Cir. 1997) (finding protectible liberty interest, based in right to privacy, under New Jersey Constitution); Roe v. Farwell, 999 F. Supp. 174, 196 (D. Mass. 1998) (finding a "protectible liberty interest in privacy and reputation created by Article 12 of the Massachusetts Declaration of Rights"); Cutshall v. Sundquist, 980 F. Supp. 928, 932 (M.D. Tenn. 1997), rev'd on other grounds, 193 F.3d 466 (6th Cir. 1999) (finding protectible liberty interest, based in right to privacy, under Tennessee Declaration of Rights and U.S. Constitution).

${ }^{31}$ Indeed, as Professor Robert Schapiro has recently noted, judicial review of legislative action at the state level "rests on stronger textual or historical foundations than its federal analogue." Schapiro, supra note 334 , at 429 . In contrast to the mere implicit (and historically controversial) provision of judicial review in the federal constitution, Schapiro observes that many state constitutions expressly permit judicial invalidation of legislative acts, and that many states over time have adopted detailed constitutional limits on legislative actions. Id. On this basis, Schapiro concludes that state courts "do not suffer from the federalism concerns that may incline federal courts to hesitate in announcing norms that will constrain governmental activity in all fifty states .... Whatever its status in the federal context, judicial review in the state setting functions as an integral part of the overall democratic system of [state] government." Id. at 42930.

42 See, e.g., ALA. CODE $\$ 15-20-20.1$ (1999) ("The system of registering criminal sex offenders is a proper exercise of the state's police power .... [Criminal sex offenders] have a reduced expectation of privacy because of the public's interest in safety and in the effective operation of government."); COLO. REv. STAT. § 18-3-412.5(6.5)(a) (1999) ("The general assembly finds that persons convicted of offenses involving unlawful sexual behavior have a reduced expectation of privacy because of the public's interest in public safety."); HAW. REV. STAT. ANN. § 846E-3 (Michie 1998) ("Relevant information that is necessary to protect the public shall be collected for purposes of making it available to the general public, and a sex offender shall have a diminished expectation of privacy in the information."); FLA. STAT. ANN. \$ 944-606(2) (West 1998) ("Sexual 
for instance, has stated that reviewing courts have a "duty" to uphold registration and notification laws, and that a court acting otherwise "unlawfully encroaches on the Legislature's exclusive power to make laws and places at risk significant public interests of the state." 343 Putting aside the unseemly nature of such saber rattling, such legislative pronouncements pose obvious separation of powers concerns. Whether state courts, in the Fourth Circuit's words, elect to indulge in "prostrate deference" to legislative findings, ${ }^{344}$ or to embrace their historic oversight role in our tripartite system, ${ }^{345}$ holds promise for additional constitutional drama in the years to come. ${ }^{346}$

Today, true to Justice Brandeis's recognition that the states "serve as a laboratory" for social experimentation, ${ }^{347}$ sex offender notification procedural law is in considerable flux, with jurisdictions employing a variety of approaches. Although perhaps cheaper than long-term prison, or indefinite "civil" com-

offenders have a reduced expectation of privacy because of the public's interest in public safety and in the effective operation of government."); LA. CODE CRIM. PROC. ANN. art. 15:540(A) (West 1998) ("Persons found to have committed a sex offense or a crime against a victim who is a minor have a reduced expectation of privacy because of the public's interest in public safety and in the effective operation of government."); OKLA. STAT. ANN. tit. 57, \$ 581(b) (West Supp. 2000) ("The Legislature finds that sex offenders ... pose a high risk of re-offending after release from custody. The Legislature further finds that the privacy interest of persons adjudicated guilty of these crimes is less important than the state's interest in public safety."); TENN. CODE. ANN. \$ 40-39-101(b) (3) (4) (1998) ("Persons convicted of these sexual offenses have a reduced expectation of privacy because of the public's interest in public safety .... In balancing the offender's due process and other rights against the interests of public security, the general assembly finds that releasing information about sexual offenders .... will further the primary governmental interest of protecting vulnerable populations from potential harm."). In a notable instance of largesse, the South Carolina Legislature was at pains to assure that its sex offender laws "are not intended to violate the guaranteed constitutional rights of those who have violated our nation's laws." See S.C. CODE ANN. \$ 23-3-400 (Law Co-op. 1999).

${ }^{3 i s}$ FLA. STAT. ANN. $\$ 775.24(1)$ (West 1998). Furthermore, the "Legislature strongly encourages" any agency adversely affected by a judicial order in the execution of the sex offender laws "to file a motion in the court that entered such order." Id. $\$ 775-24(3)$.

${ }^{s t 4}$ Brzonkala v. Virginia Polytechnic Inst, 169 F.3d 820, 847 (4th Cir. 1999) (en banc), cert. granted sub nom. United States v. Morrison, 120 S. Ct. 11 (1999).

${ }^{445}$ The Louisiana Constitution, for instance, expressly prohibits any branch from exercising power vested in another. See LA. CoNST. art II, $\$ 2$.

${ }^{316}$ As Professor Helen Hershkoff has observed, "[E]ven if one assumes that state legislatures are better equipped at fact-gathering than are state courts, it does not follow that legislatures are better positioned to use the information that they collect to achieve constitutional goals." Helen Hershkoff, Posilive Rights and Stale Constitutions: The Limils of Federal Rationality Review, 112 HARV. L. REV. 1131, 1179 (1999). Indeed, there is sound reason to dispute the accuracy and reliability of the social scientific data ostensibly relied upon by legislatures to single out sex offenders as special recidivism threats. See supra note 43 (discussing uncertainty among researchers relative to rates of sex offender recidivism).

${ }^{37}$ New State Ice Co. v. Liebmann, 285 U.S. 262, 311 (1932) (Brandeis, J., dissenting). 
mitment, registration and notification are not "cost-free"; if American jurisdictions desire to subject sex offenders to potential life-long stigmatization, and deprive them of privacy in kind, these ends must be achieved with due regard to the very substantial liberty interest at stake. ${ }^{348}$ For although sex offenders indisputably warrant our disdain, they just as assuredly are entitled to the mantle of due process protections afforded by state and federal constitutions.

${ }^{3 s}$ As the Supreme Court observed over twenty-five years ago, "[p]rocedure by presumption is always cheaper and easier than individualized determination. But when . . . the procedure forecloses the determinative issues ... when it explicitly disdains present realities in deference to past formalities, ... [i]t . . . cannot stand." Stanley v. Illinois, 405 U.S. 645, 656-57 (1972). 
